\title{
Croatian leadership and Jews in the 1990s
}

\section{Andrijana Perković Paloš}

University of Split, Faculty of Humanities and Social Sciences, Split, Croatia
Correspondence to:

Andrijana Perković Paloš

Faculty of Humanities and Social Sciences, Poljička cesta 35, 21000 Split, Croatia ppalos.andrijana@gmail.com

\section{Cite as:}

Perković Paloš A. Croatian leadership and Jews in the 1990s. ST-OPEN. 2020; 1 : e2020.1619.39.

\section{DOI:}

https://doi.org/10.48188/so.1.13
Aim: What was the attitude of the first Croatian president Franjo Tuđman and the Croatian leadership towards the Holocaust and the Jewish community in Croatia in the 1990s? Some considered Tuđman a Holocaust denier because of the purportedly controversial parts of his 1989 book Bespuća povijesne zbiljnosti (Wastelands of Historical Reality). The Croatian leadership was accused of minimizing World War II crimes of the Ustasha regime and rehabilitating the World War II Independent State of Croatia.

Methods: We analyzed archival documents, Tuđman's published correspondence, controversial parts of his Wastelands of Historical Reality, his public statements, biographical writings of contemporary Croatian leaders, and newspaper articles. We scrutinized the Serbian propaganda against Croatia in the 1990s, the position and role of the Jewish community and prominent Jews in Croatian public life as well as the relations between Croatia and Israel.

Findings: The Croatian leadership and the Jewish community maintained good relations in the 1990s. Some prominent Croatian Jews actively advocated for Croatia's international recognition and refuted certain authors' and some Jewish international circles' accusations of antisemitism among Croatian leadership. Jews participated at the highest levels of Croatian government. Democratic changes at the beginning of the 1990s enabled national, religious, political and other freedoms for minorities in Croatia, including the Jewish community. Still, some authors considered Tuđman an anti-Semite and a Holocaust denier. These opinions were partly shaped by quotes from the Wastelands of Historical Reality taken out of context and published by Serbian propagandists. This propaganda successfully shaped the false perception of official antisemitism in Croatia and has contributed to the delay in the establishment of the diplomatic relations between Croatia and Israel for more than five years after Israel had recognized Croatia.

Conclusion: There is no evidence for claims of political antisemitism in Croatia in the 1990s. This article sheds light on this widely manipulated topic and provides a basis for further researchs. 


\section{Introduction}

The collapse of the Yugoslav communist regime and the ensuing democratic elections in Croatia in the first half of 1990 marked a turning point in Croatian history. The Croatian Democratic Union (Hrvatska demokratska zajednica - HDZ) won the first democratic multiparty elections. The founder of the winning party, Franjo Tuđman, became the first Croatian president. Under new leadership, the Croatian parliament (Sabor) enacted the new constitution affirming Croatia's sovereignty from Yugoslavia. This, along with other factors, invoked a rebellion of ethnic Serbs in Croatia and resulted in an open Serbian military aggression of Croatia, which ended in Croatian victory in 1995 (Perković Paloš, 2020, pp. 267-294).

Alongside with the military aggression, Serbia launched a vigorous propaganda project against Croatia in the international community. With the experienced Serb nationalists dominating Yugoslav diplomacy and thanks to their well-established lobby at foreign power centers, Serbia depicted the Croatian authorities as Ustasha sympathizers and the Republic of Croatia as a successor to the World War II Axis-allied Independent State of Croatia (known as NDH, abbreviation for Croatian "Nezavisna Država Hrvatska”; Perković Paloš, 2018, pp. 182-186). One prominent insinuation of the propaganda concerned F. Tuđman's alleged antisemitism. This insinuation was based on excerpts from F. Tuđman's 1989 book Wastelands of Historical Reality (Bespuća povijesne zbiljnosti) and his statements during the election campaign of early 1990. The aim was to portray authorities as endangering Croatian Jews. F. Tuđman's apologies for atrocities against Jews by the NDH, the participation of Jews in his cabinet and efforts to establish diplomatic relations with Israel did not blunt the edge of Serbian propaganda.

So far historiography, both foreign and Croatian, has analyzed only cursorily the attitude of Croatian leadership and F. Tuđman towards Jews in general and the Croatian Jewish community in particular. Authors dealing with Holocaust denial such as Deborah Lipstadt and Efraim Zuroff regarded F. Tuđman as a Holocaust denier. Among F. Tuđman's prominent critics in Croatia was Ivo Goldstein, historian and former president of the Jewish community Bet Israel in Zagreb. Goldstein maintained that F. Tuđman led the rehabilitation of NDH. In constrast, American historian James J. Sadkovich tried to avoid simplified interpretations (Sadkovich, 2006; Sadkovich, 2010a; Sadkovich, 2010b). His work is only the beginning of a serious and thorough analysis of this aspect of F. Tuđman's politics. This article aims to provide an impetus to further research of this topic and F. Tuđman's policy in general.

\section{Antisemitism, Holocaust and postwar Holocaust debate}

Antisemitism is the intolerance or hatred of Jews, it has been a phenomenon present from antiquity to the modern age. Sensu stricto, it refers to the modern ideology which emerged in Central Europe at the end of the $19^{\text {th }}$ century and culminated in the first half of the $20^{\text {th }}$ century (see Beller, 2007; Vulesica, 2009; Arendt, 2015, for more detail). Most aggressive antisemitism is justifiably associated with Nazi Germany and countries that participated 
in the Nazi program of "the final solution of the Jewish question". Genocide of Jews during World War II is known as the Holocaust (Berenbaum, 2020), a term used mostly outside the Jewish community that prefers the term Shoah, Catastrophe. It is estimated that approximately six million European Jews were killed during the "final solution" (Stern, 1993, pp. 66-67).

Contemporary antisemitism includes the denial of entire the particulars or the entirety of the genocide of Jews during World War II (see Bailer-Galanda, 1997; Williams, 2012; Lipstadt, 1993; Stern, 1993; Gerstenfeld, 2009; Eaglestone, 2001, for more detail). However, Holocaust denial can be confused with revision and critical interpretation of historic events and processes based on available sources. Lipstadt (1993, p. 25) states that all historians are revisionists as they reinterpret historic events based on newly available sources or new insights. Her opinion is shared by other historians (see Petrović 2007; Birin, 2005, for more detail).

Holocaust denial first appeared in Germany and Austria (Bailer-Galanda, 1997, p. 3). Similar tendencies appeared in Western Europe. The phenomenon spread to academic circles, especially in the 1970s (Williams, 2012, pp. 82-135; Stern, 1993, pp. 25-56). Holocaust denial includes statements that Hitler did not order or did not know about the extermination of Jews, that concentration camps did not contain gas chambers, that "only" a few hundred thousand Jews were killed, and that the testimonials of the survivors are unreliable (Stern, 1993, pp. 58-81). More extreme claims suggest that Holocaust was a "Jewish conspiracy” or a "hoax" (Williams, 2012, p. 15).

Historiography and the public discourse in the Eastern Bloc differed significantly from those in Western Europe (see Đurašković, 2008, for more detail). In communist countries with limited freedom of speech, there was no serious discussion of the Holocaust. Jews were not acknowledged for the particular treatment by the Nazis. Discussion focused on the communist resistance to fascism (Fox, 2004, p. 423). Change came only with the fall of communism in 1989.

The Fall of communist regimes allowed for the entrance of right-wing parties to the political scene; some authors link it to the rise of political antisemitism (see Pecnik, 1996; Williams, 2012; Zuroff, 2005; Lobont, 2004; Shafir, 2003; Starman, 2004, for more detail). Similarly, nationalist revival in post-communist societies reached to pre-communist nationalist traditions, some of which were associated with Axis-allied states. Some authors link rehabilitation of such traditions to political antisemitism of the new democratically elected authorities.

A related phenomenon are the attempts at the rehabilitation of World War II fascist nationalists. Examples include the reappearance of public portraits of the war-time Slovakian president and war criminal Jozef Tiso who played an important role in the deportation of Jews to Auschwitz (Lipstadt, 1993, p. 16). Williams (2012) and Pecnik (1996) wrote about the rehabilitation of Romanian dictator Ion Antonescu. Russian politicians such as Vladimir Žirinovski and Natalia Naročincka publicly opposed Holocaust commemorations (Williams, 2012, pp. 48-50). Even before the breakdown of the Soviet Union in 1991, the Russian movement "Pamyat" blamed Jews for the ills of Soviet society; and with the breakdown of Soviet regime, mass nationalistic demonstrations with antisemitic overtones 
erupted (Lobont, 2004, p. 443). The Hungarian politician Istvan Csurka blamed Hungarian communists, a majority of them Jewish, for "systematically destroying the dignity of the Hungarian people" (Pecnik, 1996, p. 70). Some European politicians openly denied the Holocaust; Corneliu Vadim Tudor, a member of the far-right Party of Great Romania, stated in 1994 that Holocaust was a "Zionist scheme" (but later changed his mind; Zuroff, 2005, para. 6).

\section{Jews in the Independent State of Croatia and communist Yugoslavia}

Compared to countries like Poland, Hungary and Romania, the Jewish community in Croatia was small. At the turn of the $20^{\text {th }}$ century, there were some 20,000 Jews in Croatia, while in Hungary there were 600,000, in Romania 800,000, and in Poland 3000000 (I. Goldstein \& S. Goldstein, 2001, p. 25). The rise of the antisemitism in Croatia and the Kingdom of Yugoslavia, as well as in the rest of Europe, became evident in the mid-thirties (Švob, 1997, p. 98). American historian Esther Gitman claims that it was the members of the Serbian elites who introduced antisemitic ideology to Yugoslavia and Croatia (Gitman, 2020, p. 192). The fall of the Kingdom of Yugoslavia in April 1941 resulted in the proclamation of the Independent State of Croatia. The new state, led by the head of the Ustasha movement Ante Pavelić, was within the German and Italian zones of influence. The Ustasha regime adopted the racial laws affecting primarily Jews (see I. Goldstein \& S. Goldstein, 2001; I. Goldstein, 2008; I. Goldstein \& S. Goldstein, 2011, for more detail). During World War II about 80 percent of Jews in NDH perished (Švob, 1998, p. 299; Švob, 1997, p. 119; Karakaš Obradov, 2013a, pp. 391-404). The symbol of the Ustasha regime became Jasenovac, a concentration camp for Jews, Roma, Serbs, and Croat opponents of the Ustasha regime. Some Jews were saved thanks to the help of fellow Croats and the Archbishop of Zagreb Aloysius (Alojzije) Stepinac; rescue often included assistance in esaping (see Gitman, 2012, for more detail). Initially they escaped to NDH territories under Italian control, and from there through southern Italy to the refugee camp El Shatt in Egypt (Karakaš Obradov, 2013b, pp. 162-163, 169). Some eventually ended up in Palestine (see Karakaš Obradov, 2013b, p. 164), while others joined communist-led Yugoslavs Partisan resistance (Švob, 1998, p. 299). Some Jews were spared by the Ustasha regime due to their kinship to the members of the NDH leadership by being granted the status of "honorary Aryans." Some were spared because of the regime's need for their professional skills, for example engineers or doctors (Arendt, 1964, p. 87; Gitman, 2020, p. 200; Karakaš Obradov, 2013b, p. 177; Bartulin, 2013).

In 1945, Croatia became a part of communist Yugoslavia. Some Jews returned. Karakaš Obradov (2013a, pp. 396-397) pointed out that Croatian Jews returned mostly to Zagreb, where the local Jewish community received them. Slavko Goldstein (1998, p. 22) maintained that Jews returning to Zagreb were Partisan fighters, survivors of German concentration camps, and escapees to Italy, Hungary, and Switzerland. However, seven to eightand-a-half thousand Jews emigrated from Yugoslavia from 1948 to 1952, leaving there the total of only about 6,100 (Karakaš Obradov, 2013a, p. 403).

According to S. Goldstein, Jews enjoyed the full rights of citizenship in communist Yugoslavia; from WWII until the Six-Day war in 1967, when Yugoslavia broke off diplomat- 
ic relationships with Israel, there was no sign of any antisemitism. Yugoslav dictator Josip Broz Tito repeatedly asked the leadership of the Zagreb Jewish Community to condemn Israel, which the leadership of the Community refused (S. Goldstein, 1998, p. 25). Although assimilation of Croatian Jews began in the second half of the $19^{\text {th }}$ century (Gross, 1998, pp. 106-126; I. Goldstein, 2004, pp. 17-18), Švob (1997, p. 364), it especially accelerated during communism. Slavko Goldstein (1998, p. 24) claimed that assimilation in Zagreb could be viewed as breaking all their Jewish ties in an attempt to integrate into a wider community - that of Zagreb, Croatia and Yugoslavia. Nevertheless, he stressed that this attitude was shared only by a minority of Zagreb Jews. Goldstein mentioned "dualism” of Jewish identity, although he did not specify whether he was referring to Croatian or Yugoslav identity along with Jewish identity. Similarlto other communist European countries, Yugoslav regime commemorated the Jewish victims of World War II by emphasizing the narrative of the "struggle for national liberation" and "brotherhood and unity" (Kerenji, 2008, p. 182). Examples of this practice are the five monuments erected in 1952 and dedicated to Yugoslav Jewish victims that did not differentiate Jews as Holocaust victims, but referred to them simply as "Jewish victims of fascism" (Kerenji, 2008, p. 183).

\section{Franjo Tuđman and Wastelands of Historical Reality}

Just like public discourse in general, the historiography of World War II in communist Yugoslavia was under strict control (see Najbar Agičić, 2013; Bertoša, 2005; I. Goldstein, 2005, for more detail). Postwar extrajudicial mass executions of defeated military and civilians, known as Bleiburg massacres (Jurčević, 2005), could not be discussed, while the number of Jasenovac camp victims was greatly and uncritically exaggerated. Estimates ranged from several thousand to as much as one million victims (Geiger, 2020). Prominent Croatian historian Ivo Banac (1992, p. 68) suggested that in this way some academic circles aspired to "demonize Croatian people".

Among the most distinguished scholars opposing the exaggerations was Yugoslav general and former Partisan fighter Franjo Tuđman. In 1961, F. Tuđman became the head of the newly established Institute for the History of the Worker's Movement of Croatia. The institute studied the history of the Communist party of Croatia, national liberation struggle, socialist revolution, Ustasha movement, and the NDH. F. Tuđman's research focused on the role of Croat resistance to occupiers and the position of Croatian people in the NDH and Ustasha movement (Jareb, 2011, p. 280). His conclusions did not match the official Party interpretation of World War II history of Croatia and Yugoslavia, particularly the number of Jasenovac victims (Sadkovich, 2010a, p. 116). For that, F. Tuđman was expelled from the Communist Party and the Institute in 1967. Sadkovich (2010a, p. 150) claims the reason for F. Tuđman's expulsion was not because of "poor academic work," but due to "deviation from the Party line" and that F. Tuđman was not interested only in "accuracy", but wanted to "remove the burden of war guilt from the shoulders of Croats" (Sadkovich, 2010a, p. 344).

F. Tuđman dealt with the issue of the Jasenovac victims in Wastelands of Historic Reality (also known as Horrors of War). His aim was to dispute the allegation of genocidal nature not only of Croats, but also of any other national, ethnic and religious groups. Some of 
his interpretations of Yugoslav history were, in fact, a reaction to Serbian nationalist historiography which in communist Yugoslavia did all that was possible to mark Croats as genocidal (Sadkovich, 2010a, pp. 277-278; Banac, 1992, p. 68). During the decade after Tito's death in 1980, Serbian nationalism rose to unprecedented heights. This emboldened some historians to present the Chetniks (Serbian chauvinist collaborationists who committed crimes against Croats and Muslims) in positive light (Ramet, 2005, p. 43) leading to tendencies in Serbia to rehabilitate them (Ramet, 2005, p. 47). Three years before Wastelands, in 1986, the Serbian Academy of Science and Arts published its Memorandum (Memorandum of the Serbian Academy of Sciences and Arts, draft, 1986). The Memorandum promulgated the thesis of assimilation and endangerment of the Serbs in Croatia (Memorandum of the Serbian Academy of Sciences and Arts, draft, 1986, p. 25). About that time, Serbian historian Vasilije Krestić published his claims on the genocidal nature of the entire Croatian nation (Sadkovich, 2010a, 260; I. Goldstein \& Hutinec, 2007, p. 192).

In Wastelands, F. Tuđman (1989, p. 98) emphasized that "had the Ustasha crimes been lessened as many times as they [Serbs] have exaggerated them, they would still be utterly atrocious and enormous!” (F. Tuđman, 1989, pp. 20-21). "As we have seen, the entire Jasenovac myth (emphasized in the original) has been orchestrated as if such a genocidal crime had not occurred not only within the framework of World War II, but throughout the entire history” (F. Tuđman, 1989, p. 464). Positing that historic guilt and collective genocidal stigma can be imposed neither on the entire Croat people nor on new generations of Croats, Wastelands deals with genocidal acts from the beginning of written history until the time of finishing the manuscript. Together with the fate of Croats, the book scrutinized the fate of Jews, the hate, discrimination and persecution of the Jewish people through history. Discussing Jewish victims of the Holocaust, he wrote that "no matter how terrible and widespread, unfortunately they were neither a singular nor an exceptional occurrence in any historical period. There is just a greater historical memory of them than of other genocides against other nations” (F. Tuđman, 1989, p. 143). Emphasizing the significance of Wastelands, Banac (1992, p. 68) called that book "a capital charge against the system of demonization of the Croatian people”.

\section{Wastelands Controversy}

Controversial parts of the Wastelands include recollections of prisoners of Jasenovac on the role Jews played in the camp. Two were Serbs, Vojislav Prnjatović and Branko Popović. F. Tuđman took their statements from document collection of the Belgrade historian Antun Miletić (1986-1987). The third was Ante Ciliga, a Croat and member of the Politburo of the Central Committee of the Communist Party of Yugoslavia in the beginning of the 1920s. Ciliga described his one-year stay in Jasenovac in his memoirs Alone Through Europe in War (Ciliga, 1978). According to Prnjatović and Ciliga, Jews had a considerable role in the camp's administration. Prnjatović claimed that three of 25 members of the camp administration were Serbs, while others were Jews (F. Tuđman, 1989, p. 317). Prnjatović thought that Jews, compared to Serbs, had been privileged. According to Prnjatović, "a Jew remains a Jew, even in the Jasenovac camp. In the camp they not only maintained all their flaws, but made them even more visible. Selfishness, cunning, unreliability, stinginess, perfidy and confidentiality are their main features” (Miletić, 1986-1987, p. 106). F. Tuđman dis- 
tanced himself from this statement, concluding that "Prnjatović's judgment radiates with immoderation, one can even say with an antisemitic view," but he also warned that "some other witnesses made similar claims as well.” He referred to Branko Popović who claimed that some Jewish prisoners from the camp administration participated in the killings of other prisoners (F. Tuđman, 1989, p. 318). With the statements of Prnjatović and Popović one had to be careful, seeing that they testified to this in Serbia during the quisling regime of Milan Nedić which was extremely antisemitic (Lebel, 2007, pp. 330-331). According to Sadkovich (2010a, p. 270), F. Tuđman "could not easily dismiss" the testimony of Ciliga.

F. Tuđman's main thesis was that any national, ethnic, or religious group battling for survival can act genocidally towards another nation or group it considers dangerous to its existence (F. Tuđman, 1989, p. 161). F. Tuđman found the main argument for this thesis in the war of Israel and Palestinians. He criticized Israeli politics towards Palestinians, emphasizing the "small historic step from Nazi-fascism to Judeo-Nazism." He referred to the horrific experience of the Holocaust after which Jews carried out "such cruel, genocidal politics that it is rightly christened Judeo-Nazism” [F. Tuđman's emphasis], a term taken from Israeli academic Yeshayahu (Josef) Leibowitz (F. Tuđman, 1989, p. 160). Sadkovich (2010a, pp. 264-265) characterized Wastelands as a "review of people's inhumanity towards people throughout history", whereas by the use of phrase "Judeo-Nazism" and by highlighting Israeli politics towards Palestinians F. Tuđman alluded that even "victims can make others victim," in other words, that no nation is exclusively the aggressor or the victim.

\section{Slavko Goldstein's reaction to Wastelands and Franjo Tuđman's response}

Soon after the publication of Wastelands, the Jewish Community of Zagreb led by Slavko Goldstein reacted. Goldstein published an open letter to F. Tuđman announcing cessation of co-operation with Matica hrvatska, the publisher of the book (S. Goldstein, 1989, p. 19). Goldstein resented F. Tuđman for not questioning the credibility of witnesses or the circumstances of testimony on the position of Jews in Jasenovac, while opposing "generalizations about Croatian people" such as the inference that all Croats are responsible for the crimes of the Ustasha. Goldstein implied that F. Tuđman's intention was to justify genocide, and particularly condemned using the phrase "Judeo-Nazism." According to S. Goldstein, the Executive Board of the Jewish Community of Zagreb scrutinized only pages 316 to 318 "which considers as proof for a strong argument for its extremely unfavorable attitude towards this book of dr. F. Tuđman, and also towards the publisher that published it unreservedly" (S. Goldstein, 1989, p. 19). F. Tuđman (1995, p. 693) resented S. Goldstein for the open letter for "stamping a mark of antisemitism" on him and "everything that the Publishing house of Matica hrvatska symbolizes” as a Croatian national institution. He described his own book as "historical and philosophical deliberation of genocidal iniquities and violence throughout history" (F. Tuđman, 1995, p. 689), noting that he does not justify any crime, let alone genocide, but he "searches for causes and assumptions for the removal of any iniquities and violence” (F. Tuđman, 1995, p. 695). He also emphasized that he had not given any significant meaning to the testimonies of Prnjatović and Ciliga, stressing his own reservation that he adduced in his book (F. Tuđman, 1995, p. 693).

Ivo and Slavko Goldstein (2001, p. 602) suggest that F. Tuđman did not dissociate himself from Prnjatović's testimony clearly and decisively, thus reducing the responsibility of the 
Ustasha and blaming the Jews culpability in Jasenovac. I. Goldstein \& S. Goldstein (2001, p. 600 ), hence, placed the book at the very "foundations of Croatian revisionism".

\section{Other Reactions to Franjo Tuđman's Statements in Wastelands}

In some international circles F. Tuđman was criticized for alleged Holocaust denial even more severely. Accusations started after he assumed the Croatian presidency in 1990. Atkins (2009, p. 139) called him an antisemite. Some wrote about F. Tuđman's "antisemitic statements” in the Wastelands (Živković, 2000, p. 75). Sadkovich (2010b, p. 11) mentions historian Robert Hayden, who called F. Tuđman a racist and an antisemite. Robert Kaplan evaluated F. Tuđman's book as antisemitic (Sadkovich, 2006, p. 263). Using only secondary literature, without citing Wastelands, some authors attributed Prnjatovićs statements which F. Tuđman had cited in his book to F. Tuđman, as if they were his very own. Some authors who mentioned Wastelands have never actually read the book. For example, in 1991 Kaplan wrote an article critical of Wastelands accusing F. Tuđman of Holocaust revisionism, attributing to him Prnjatović's statements (Sadkovich, 2006, p. 263). Sadkovich emphasized that it was not clear how Kaplan was aware of this, since he did not read Croatian and there was no translation of Wastelands until 1996 (Sadkovich, 2006, p. 263). Katarina Mijatović, who later translated Wastelands into English, responded to Kaplan's article, accusing him of "having quoted F. Tuđman out of context and of having attributed quotes from other sources to him" (Sadkovich, 2006, p. 264). Kaplan responded to Mijatović' s letter, admitting that he had not read the book, but that he took some F. Tuđman's statements from a translation (of questionable credibility) which was also used by some other journalists (Sadkovich, 2006, p. 264). Sadkovich claimed that these journalists read only an "unauthorized ten-page translation” of F. Tuđman's 505-page book (Sadkovich, 2006, p. 265).

Some authors explicitly related F. Tuđman to Nazis. They based their allegations on an unauthorized Belgradian translation of excerpts from F. Tuđman's book. Shortly after Croatia's recognition by the European Community (EC) at the beginning of 1992, journalist Teddy Preuss from the influential newspaper The Jerusalem Post International titled an article on F. Tuđman “Goebbels lives in Zagreb” (Radoš, 2005, p. 144). Other scholars alleged that F. Tuđman himself represented the thesis that Jews carried out the Holocaust (Lobont, 2004; Shafir, 2003; Zuroff, 2005; Starman, 2004).

Lobont (2004, p. 458) argued that F. Tuđman intended to "cover up" Pavelićs crimes. However, errors in his text reveal poor familiarity with the work he criticizes. Examples include the erroneous quoting of the publication year of the Wastelands (1988 instead of the correct 1989) and misnaming Jasenovac as Jasenovać (Lobont, 2004, p. 458).

Stern (1993, pp. 39-40) alleges F. Tuđman was a Holocaust denier, among other things, because of his use of the phrase "Judeo-Nazism." Lipstadt (1993, pp. 15, 35) stated that F. Tuđman wanted to downgrade the importance of the Holocaust, but she did not back up that statement with any relevant primary sources. Her insufficient precision indicates the lack of differentiation between Croats and members of the Ustasha movement. 


\section{War Victim Numbers in Wastelands}

Some authors resented F. Tuđman because he discussed the number of war victims (Stern, 1993, p. 39; Atkins, 2009, pp. 139-140). F. Tuđman disagreed with the exaggerated number of casualties at Jasenovac which was unsupported by evidence. He estimated that the number of victims was somewhere between 30,000 and 40,000. Because after Serbs, Jews had been the largest group in Jasenovac, his estimate was enough to be accused of Holocaust denial. F. Tuđman (1989, pp. 155-158) pointed out the different estimates of the total number of Holocaust victims ranging from four to six million, in agreement with Stern's references (1993, pp. 66-67). F. Tuđman did not present new estimates of the number of perished European Jews, but only described differences in standard academic publications. There is no evidence that he tried to diminish the Holocaust. However, reassured by his own research and the conflict with communist authorities, he indicated the difficulties in ascertaining the exact number of casualties in such mass sufferings (Sadkovich, 2010a, pp. 265-266).

Table 1 is a partial list of Wastelands detractors. Interestingly, among the eight highly critical authors, only two referenced Wastelands, even though the book was their main argument for accusing F. Tuđman of antisemitism, diminishing of Ustasha crimes, and accusing Jews of perpetrating Holocaust in Jasenovac.

Table 1. Reactions to Wastelands

\begin{tabular}{|c|c|c|c|}
\hline Author & $\begin{array}{l}\text { Claims about Wastelands and } \\
\text { F. Tuđman }\end{array}$ & Argumentation & $\begin{array}{c}\text { Cited } \\
\text { Wastelands }\end{array}$ \\
\hline $\begin{array}{l}\text { Atkins, S. } \\
(2009)\end{array}$ & $\begin{array}{l}\text { F. Tuđman antisemite. } \\
\text { Attempted to minimize } \\
\text { Ustasha crimes in Jasenovac. }\end{array}$ & $\begin{array}{l}\text { F. Tuđman's estimates of the number of Holocaust victims } \\
\text { from four to six million linked to his Holocaust denial. Ignores } \\
\text { F. Tuđman's references to relevant academic publications. }\end{array}$ & Yes \\
\hline $\begin{array}{l}\text { Lipstadt, D. } \\
\text { (1993) }\end{array}$ & $\begin{array}{l}\text { F. Tuđman diminished signifi- } \\
\text { cance of Holocaust. }\end{array}$ & $\begin{array}{l}\text { F. Tuđman's "biased testimonies and exaggerated data" on the } \\
\text { number of Holocaust victims. Ignores F. Tuđman's references } \\
\text { to academic publications.* }\end{array}$ & No \\
\hline $\begin{array}{l}\text { Lobont, F. } \\
(2004)\end{array}$ & $\begin{array}{l}\text { F. Tuđman considered Jews } \\
\text { perpetrators of Holocaust in } \\
\text { Jasenovac. }\end{array}$ & Attributed Prnjatović's statements to F. Tuđman. & No \\
\hline $\begin{array}{l}\text { Shafir, M. } \\
(2003)\end{array}$ & $\begin{array}{l}\text { F. Tuđman considered Jews } \\
\text { perpetrators of Holocaust in } \\
\text { Jasenovac. Called F. Tuđman } \\
\text { antisemite. }\end{array}$ & Attributed Prnjatović's statements to F. Tuđman. & No \\
\hline $\begin{array}{l}\text { Starman, H. } \\
(2004)\end{array}$ & $\begin{array}{l}\text { F. Tuđman considered Jews } \\
\text { perpetrators of Holocaust in } \\
\text { Jasenovac. }\end{array}$ & Attributed Prnjatović's statements to F. Tuđman. & Yes \\
\hline $\begin{array}{l}\text { Stern, K. } \\
\text { (1993) }\end{array}$ & $\begin{array}{l}\text { Considered F. Tuđman a } \\
\text { Holocaust denier. }\end{array}$ & $\begin{array}{l}\text { Linked F. Tuđman's estimates of Holocaust victims from four } \\
\text { to } 6 \text { sixmillion to his Holocaust denial. Ignored F. Tuđman's } \\
\text { references to the academic publications. }\end{array}$ & No \\
\hline $\begin{array}{l}\text { Zuroff, E. } \\
(2005)\end{array}$ & $\begin{array}{l}\text { F. Tuđman considered Jews } \\
\text { perpetrators of Holocaust in } \\
\text { Jasenovac. }\end{array}$ & Attributed Prnjatović's statements to F. Tuđman. & No \\
\hline $\begin{array}{l}\text { Živković, M. } \\
(2000)\end{array}$ & $\begin{array}{l}\text { F. Tuđman's statements in } \\
\text { Wastelands are antisemitic. }\end{array}$ & No argument for the claims. & No \\
\hline
\end{tabular}

*F. Tuđman cited relevant Holocaust experts and institutions, e.g., Reitlinger, G. (1953), Levin, N. (1973) and Hilberg, R. (1973).

\section{Later edition of Wastelands}

To diminish the negative impact of the book, in January $1992 \mathrm{~F}$. Tuđman wrote to Edgar Bronfman, president of the World Jewish Congress. He emphasized his dedication to "re- 
searching the horrors of iniquities and violence, which in recent history had been done to Jewish people," but some parts of his book "were maliciously interpreted as historical revisionism or antisemitism. As a former antifascist fighter and committed democrat, I deny every such intention” (M. Tuđman, 2015a, pp. 111-116).

Antipathy to F. Tuđman was evident at the opening of the US Holocaust Memorial Museum in Washington in April 1993. Invitation to F. Tuđman to the opening (M. Tuđman, 2015b, p. 130) caused a harsh reaction of Holocaust survivor and Nobel Prize winner Elie Wiesel. Wiesel stated that F. Tuđman's presence among Holocaust survivors would be shameful (Birnbaum, 1993). Julienne Eden Bušić, an advisor in the Croatian Embassy to the USA, claims that F. Tuđman arrived to the USA in an atmosphere where "Americans did not have any idea whom to trust, they were all thoroughly confused” (Radoš, 2005, p. 144). Some claimed that members of the Serbian lobby in Washington had taken quotes from Wastelands out of context and sent them to numerous diplomatic addresses (Radoš, 2005, pp. 143, 145-146) strengthening the snubbing of F. Tuđman and deepening the misperception of his stance towards Jews (Radoš, 2005, p. 146).

On February 14, 1994 F. Tuđman sent a letter to Kent Schiner, president of B’nai B'rith, apologizing and announcing a new edition of the book, where he would remove the controversial quotes (Radoš, 2005, p. 145). The new edition of the Wastelands, without the quotes, was published in 1996 and F. Tuđman sent it to the Chairman of the Council Holocaust Memorial in the USA, Miles Lerman (M. Tuđman, 2015d, pp. 368-370). Figure 1 presents a timeline of events related to F. Tuđman, Wastelands and Croatian leadership until the establishment of diplomatic relations with Israel in 1997.

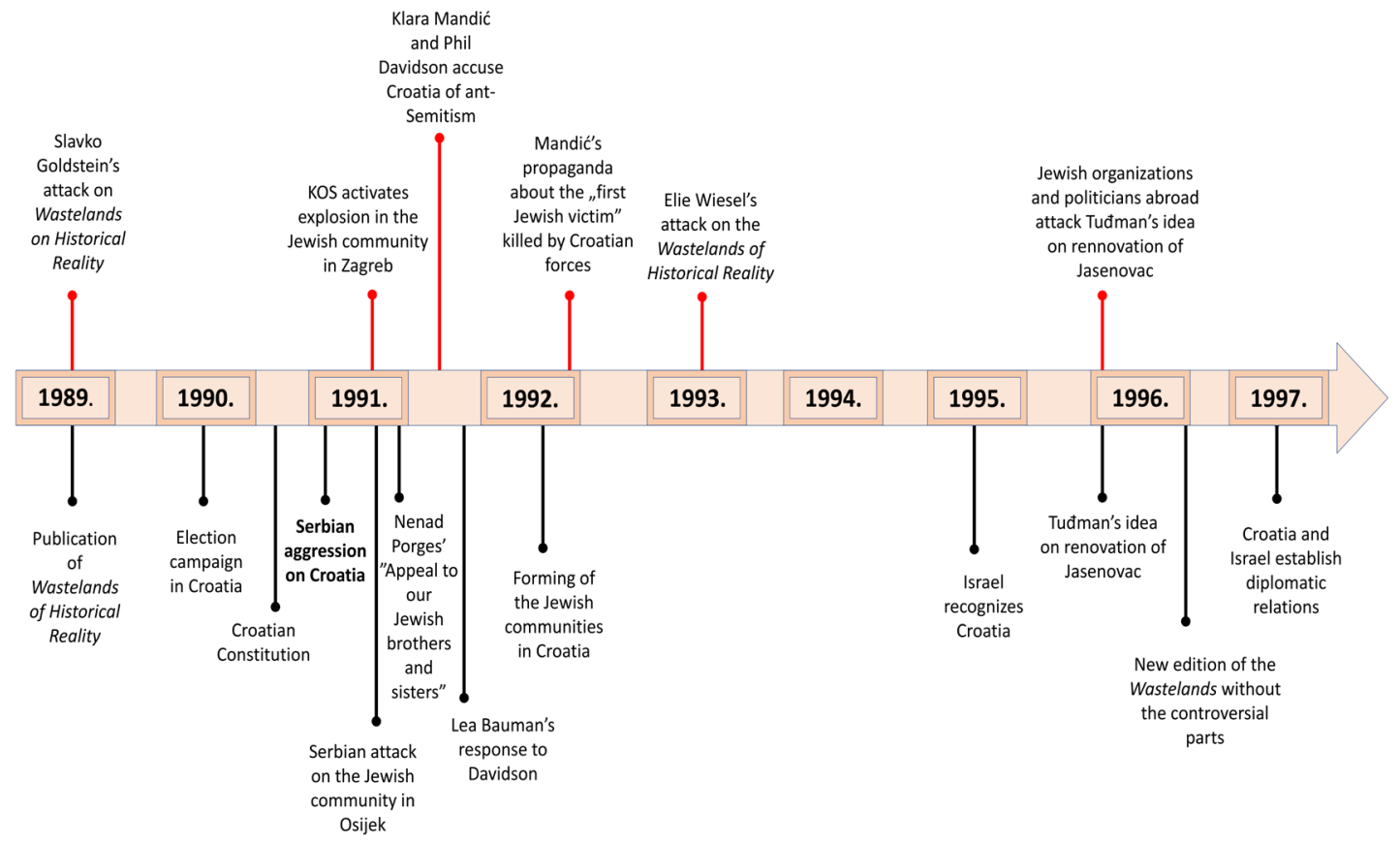

Figure 1. Events pertinent to Tuđman, Wastelands and Croatian leadership 1990-1997. KOS - Counterinelligence service of the Yugoslav People's Army; Nenad Porges - president of the Council of the Jewish Community in Zagreb - wrote the "Appeal to our Jewish brothers and sisters" in which he appealed for the international recognition of Croatia and support for the Croatian War of Independence. 


\section{Political discourse in Croatia in early 1990 s}

The breakdown of the one-party regime which had a monopoly on interpretation of World War II and its aftermath enabled free public speaking about historiographic controversies. In Croatia that meant free discussions about Partisan mass executions of the defeated NDH military and civilians who had surrendered in May 1945 (B. Matković, 2011). In addition, Milošević's aggressive rhetoric (Barić, 2005, p. 43) and insurgency of ethnic Serbs (Barić, 2005, pp. 77-85) affected the discourse among the newly established political parties in Croatia. It gave a voice to right-wing groups (Jolić, 1991, pp. 3-4) and intensified the rhetoric of a part of Croatian leadership and opposition (Barić, 2005, pp. 136-137). Some authors considered the activity of right-wing parties as leading to an increase in antisemitism asserting that Croatian leadership "included it in its political program” (I. Goldstein \& S. Goldstein, 2011, p. 242; I. Goldstein \& Hutinec, 2007, p. 188; I. Goldstein, 2005, p. 60; I. Goldstein \& S. Goldstein, 2001, p. 597).

Establishment of democracy and Croatian efforts to reorganize Yugoslavia into a confederation (Nazor, 2011, p. 56) were accompanied by public discourse abundant with references to Croatian history. The aim of emphasizing the long tradition of Croatian statehood was to affirm the legitimacy of the new political framework. Similarly to other post-communist countries that referred to pre-communist regimes, some Croatian political parties invoked traditions of the NDH (Cipek, 2011, pp. 13-27; Pavlaković, 2011, pp. 215-238; Radonić, 2011, pp. 355-367; Koren, 2011, pp. 123-156) boosting the allegations that F. Tuđman and his party were attempting to minize Ustasha crimes (I. Goldstein, 2002, p. 76).

\section{Franjo Tuđman and HDZ: politics and statements}

To some circles, F. Tuđman was as unaccebtable as a statesman as he was an academic, especially in his attitude towards the NDH. The three pillars of F. Tuđman's party were the idea of an independent state formulated by Ante Starčević in the $19^{\text {th }}$ century, the political teachings of Stjepan Radić, founder of the Croatian People's Peasant Party, and the positive legacy of the Croatian political left (i.e., Croatian worker's movement before World War II and resistance during World War II; Programske zasade i ciljevi HDZ, 1990, p. 9). Apparently, the HDZ program did not include reference to the Ustasha movement or NDH regime. During the 1970s and the 1980s in statements to West-European media, F. Tuđman emphasized the large-scale participation of Croats in the WWII Partisan resistance, and rejected any sympathy for the Ustasha and the NDH. For F. Tuđman, a former Partisan resistance member, fascism was completely unacceptable, as he stated without hesitation during a lecture to Croatian emigrants in Sweden (F. Tuđman, 1995, pp. 735-736; Jareb, 2011, p. 318).

A critical component of the HDZ platform was the all-Croat national reconciliation (Nazor, 2011, p. 203; Radoš, 2005, pp. 38-42). This idea is still discussed by historians, political scientists, journalists and the public in general. Some consider this policy as a means to overcome and/or avoid ideological conflicts among new Croatian generations given that a significant number of their fathers fought on opposite sides during WWII. The underlying idea is that reconciliation has been achieved through participation of descendants in defense of Croatia against Serbian aggression of 1991-1995 (Barić, 2007, pp. 213-214; Cipek, 
2007, p. 20; Nazor, 2011, p. 203). Others interpret it as a futile attempt to reconcile irreconcilable ideologies of fascism and antifascism (Boljkovac, 2009, p. 311; Čulić, 2014, p. 129) which opened the door to rehabilitation of the NDH (Hudelist, 2004, p. 686; Pavlaković, 2009, p. 168; S. Goldstein, 1993, pp. 13-18; I. Goldstein \& Hutinec, 2007, p. 195; I. Goldstein \& S. Goldstein, 2011, p. 206). Ivo Goldstein (2002, p. 76) claimed that HDZ wanted to change the negative perception of the Ustasha movement, i.e., to dismiss its fascist ideology.

\section{Franjo Tuđman's statement on NDH}

The most frequently cited evidence for the claim of F. Tuđman's revisionism is a speech delivered at the First General Convention of the HDZ, February 24-25, 1990 where he referred to the NDH:

"Supporters of the hegemonic Unitarian or Greater Yugoslavia beliefs see in the goals of HDZ's program nothing but a demand for the renewal of the Ustasha NDH. They forget that the NDH was not merely a 'quisling' formation and a 'fascist crime' but also an expression of the historical aspirations of the Croatian people for its independent state, as well as knowledge of international factors, in this case the government of Hitler's Germany, which in the ruins of Versailles dictated the new European order, of these Croatian aspirations and its geographical boundaries. Therefore, the NDH did not only represent the mere whimsy of the Axis powers but it was the outcome of quite specific historical factors" (Programske zasade i ciljevi HDZ, 1990, pp. 9-10).

Further he addresses antifascism and the historiographically often neglected Federal State of Croatia (Jareb, 2011, p. 299; Barić, 2011, p. 320; S. Matković, 2011, p. 118). F. Tuđman emphasized that "with the Federal State of Croatia established by ZAVNOH [National Antifascist Council of the National Liberation of Croatia], Croat people at the end of World War II were on the side of victorious democratic forces," and the existence of the Socialist Republic of Croatia "as national state of the Croatian people" provided the basis "for the realization of the full-state sovereignty of the Croatian people" (Programske zasade i ciljevi HDZ, 1990, pp. 12-13). The statement clearly shows that F. Tuđman considered Socialist Republic of Croatia, as a co-equal republic in the Yugoslav federation and established on "antifascist foundations," as the foundation of independent and democratic Republic of Croatia. This was emphasized later in the historical preamble of the Constitution of the Republic of Croatia enacted on December 22, 1990. The Constitution expressed Croatian sovereignty "as opposed to the proclamation of Independent State of Croatia (1941) in the decisions of the National Antifascist Council of the National Liberation of Croatia (1943), then in the Constitution of the People's Republic of Croatia (1947) and later in the constitutions of the Socialist Republic of Croatia (1963-1990)" (Ustav Republike Hrvatske, 1990). However, soon after F. Tuđman's speech, in the context of the statement regarding the $\mathrm{NDH}$, the leader of reformed Communists Ivica Račan called HDZ the "party of dangerous intentions” (Tuđen, 1990, p. 5). Referring to Račan's statement, at the HDZ election rally in Dalmatia in mid-April 1990, F. Tuđman decisively rejected any link with the NDH:

"Therefore, do not let them say that HDZ is going to rehabilitate some Ustasha NDH which was established within Hitler's order, which had to give up Dalmatia, the cradle of Croatian Statehood, to the Italians. We know that, but we also know what 
that the Croatian people have always wanted their own state, and as they today" (Marić, 1990, p. 6).

The statement was ignored in Croatian and international historiography as well as by the public, whereas the speech at the First General Convention was often emphasized out of context (Čulić, 1999, p. 20; I. Goldstein \& S. Goldstein, 2011, pp. 299-300; I. Goldstein \& Hutinec, 2007, p. 195; I. Goldstein, 2008, p. 777; I. Goldstein \& S. Goldstein, 2001, pp. 597, 609). Ivo Goldstein (2008, p. 777) claims that this statement contributed to rehabilitation of NDH and the Ustasha regime "even though F. Tuđman distanced himself from the statement, understanding all the danger that has arisen from it.” I. Goldstein (1998, p. 186) does not identify HDZ leadership with the Ustasha regime, but considers it to be "unacceptably tolerant towards right-wing diaspora”. Historian Mario Jareb (2011, pp. 297-298) disagrees and maintains that F. Tuđman just tried to clarify his misinterpreted words and calls attention to the content of the entire speech. For example, in an interview to Der Standard in 1992, F. Tuđman stated that even in World War II Croats had aspired to their own state and that in all of Yugoslavia, the resistance during WWII was the strongest in Croatia (see F. Tuđman, 1999, p. 206). Referring to his own statement at the Fourth General Conference of HDZ F. Tuđman (1998, p. 15) said:

"Because we were followers of everything positive, from Croatian nobility to civil and socialist worldviews; that we knew about the aspiration of the Croatian nation, just as that of any other nation under the sun, that it wants to be its own state, to be a subject and not an object in international life, and because of that, to the indignation of many, we said at our first Conference that the establishment of the $\mathrm{NDH}$, in the framework of Hitler's order, was not only a fascist creation, but it was also an aspiration of the Croatian people for its own state. But at the same time, then and now, we condemned and do condemn the Ustasha regime of the NDH. We condemned it because of the introduction of the Nazi regime of dictatorship, its political and racial persecutions and crimes, not only against the Jews, Serbs and communists, but also against Croatian antifascists and democrats.”

F. Tuđman emphasized the role and importance of the resistance in Croatia as one of the "strongest antifascist movements in Europe," particularly considering that the National Antifascist Council of National Liberation of Croatia is "the starting point for the constitutional and legal design as well as justification of the establishment of our independent and sovereign and democratic Croatia” (F. Tuđman, 1998, p. 19).

At the time of the $50^{\text {th }}$ anniversary of Victory in Europe, F. Tuđman was the only head of state who was active in resistance. He participated in ceremonies in London, Paris and Moscow (M. Tuđman, 2015c, p. 311; Radoš, 2005, 46). F. Tuđman authored numerous monographs, scholarly papers and discussions condemning the Ustasha regime. He never said or wrote anything positive about Ante Pavelić or tried to justify or reduce his crimes, whereas he positively assessed the historical role of Josip Broz Tito.

\section{Franjo Tuđman's statement on nationality of his wife}

F. Tuđman's statement at the HDZ election rally on April 16, 1990 in the Zagreb suburb of Dubrava on the nationality of his wife has been used as another proof of his racism and 
antisemitism. The statement is often quoted as: "Some claim that my wife is Serbian, but I am happy that she is neither Serbian nor Jewish” (I. Goldstein, 2008, p. 761; I. Goldstein, 2010, p. 222). In their book The Death of Yugoslavia british journalists Laura Silber and Allan Little (1996, p. 75) wrote that Tuđman said "I am grateful to God that my wife is neither Jewish not Serbian”. Croatian newspapers did non report the statement immediately after the rally, but Feral Tribune referred to it in 1996 reviewing the book (Hedl, 1996, pp. 38-39). Sociologist and F. Tuđman's son Miroslav Tuđman (2012, p. 92) quotes the speech with the controversial sentence:

"Today [they] spread all sorts of lies, I do not know what else they will come up with. I have heard that I am of Jewish origin, whereas I had found out, I had known that I had ancestors in Zagorje going back 350 years, and I said, maybe it would be good if I had some of that, I guess I would be richer, maybe I would not have become $a{ }^{*}$ communist. Then, when that was not enough, then [they] found my wife to be one moment a Jew, one moment a Serb. Luckily, she was never either of those, as many of them are. And so on and so on spreading lies...”

M. Tuđman (2012, p. 92-93) claims that the context of the statement referred to the context of the time, society and policy in which F. Tuđman built his career; in communism, it was favorable to one's career to display antinational and antireligious orientation by marrying into another nationality and religion. According to M. Tuđman, his father said he did not yield to pressure. Nevertheless, a more thorough and precise interpretation of F. Tuđman's sentence requires further study. Referring to his statement to the French $L e$ Figaro in 1992 F. Tuđman stated: "This sentence was taken out of context. It is nonsense. I had Jewish friends, I still have” (F. Tuđman, 1999, p. 227).

\section{Other Croatian politicians on NDH in the 1990s}

Other politicians also opined on the NDH. In an interview to the Croatian newspaper Slobodni tjednik, Marko Veselica, a dissident and prisoner of the communist regime, stated that at the establishment of the NDH Croats strived to achieve an independent state. However, his Hrvatska demokratska stranka (Croatian Democratic Party) "does not want to identify with any concrete regime” (Tardelli, 1991, p. 54). Stipe Mesić, first Croatian prime minister and the last chair of the Presidency of the Socialist Federative Republic of Yugoslavia in 1991, was positive about the NDH. During a celebration of Croatia's National Day in Australia in May 1992 he asserted:

"We created the state after nine hundred years, but within those nine hundred years Croats have not rested. They have always strived for the Croatian "thing" [national sovereignty] and a Croatian state. Even in World War II, Croats won twice and we have to say that to everyone, to friend and foe. Croats won in forty-one when on April $10^{\text {th }}$ the Croatian state was proclaimed. Croats did not proclaim that state because they were fascists, but because they had a natural and historical right to a state. But the results of World War II are known. It is also known that Croats won a second time in that war because they found themselves together with the Allies on the winning side. And to those who think that Croats were on the other side, to those who want to beat those Allies and mock Croatian work, we must say to them, 
Croats were for the Croatian state, and they did not fight for white, nor for red flags.

Croats fought only for a red, white and blue flag (Anonymous, 2013).

Still during the 1990s, talking about the "double Croat victory" in World War II and referring to expectations that Croatian authorities come to Jasenovac and apologize for Ustasha crimes, Mesić said that "we do not have any reason to apologize to anyone" and "we do not have to kneel before anyone" (Anonymous, 2007). Having been elected Croatian president in 2000, he reflected on his statements on several occasions; they varied from claims that he said what the public wanted to hear to those that he was misled by the atmosphere where, according to him, the NDH was perceived positively (Mesić, 2006, 2010). Mesić's statements on the NDH from the 1990s have been overshadowed by F. Tuđman's statements. F. Tuđman's, Veselica's and Mesić's statements indicate they differentiated the aspiration for Croatian statehood on one side from the Ustasha regime on the other.

\section{Right-wing parties on NDH and Jews}

Dobroslav Paraga, president of the Hrvatska stranka prava, (Croatian Party of Rights, HSP) glorified the NDH and Ante Pavelić. He considered Pavelić a reformer of the Croatian state (Klancir, 1991, p. 12). According to Paraga, "some crazy laws were written under German pressure,” but “none of those applied in Croatia” (Grakalić, 1991, pp. 20-21). The first general conference of HSP rejected any kind of Yugoslavia and requested the Croatian Parliament to "immediately proclaim the Independent State of Croatia" (Jolić, 1991, pp.34). They demanded April 10, the date of proclamation of the NDH in 1941, be proclaimed a state holiday (Jolić, 1991, pp. 3-4). According to the media, at the September 1991 HSP demonstrations titled "Za dom spremni!" (For Homeland Ready!) held in at the main Zagreb square, demonstrators displayed Ustasha iconography (Batušić, 1991, pp. 23-25).

In June 1991, HSP established the party’s paramilitary "Hrvatske obrambene snage" (Croatian Defense Forces, HOS). "Hrvatske oružane snage" and abbreviation HOS stand also for the NDH military adopted in 1944. The Ninth Battalion "Rafael Vitez Boban" from Split, a part of HOS, contained the special unit, the "Black Legion" in reference to its WWII NDH namesake (Matošić, 1991, p. 6). Such iconography was used to corroborate the accusations that Croatia is renewing NDH. In October 1991, F. Tuđman stated that the international community's only criticism of Croatia referred to the HOS:

"They reproached me in den Haag that we in Croatia have military formations that wear insignia from the last war and that we do not control them. I assured them that we would include those formations into the Croatian Army, and if they refuse, we will disarm them" (Butković, 1991, p. 29).

That same month F. Tuđman signed an executive order prohibiting any political activity in the military (Gregurić, 1998, p. 93). Next month, Paraga was arrested and charged with planning a coup. Although there was no solid evidence for the accusation, his aggressive rhetoric announcing a rally against the president and government provided the ground for the leadership to act. In an interview to Le Figaro in 1992, F. Tuđman was negative about Paraga who aspired "to increase cryptofascist tendencies” (F. Tuđman, 1999, p. 227). Although HSP tried to rehabilitate certain aspects of the NDH, they did not display any antisemitism. In August 1992, five HSP representatives were elected to the Croatian parlia- 
ment (Mašić, 2010, p. 71). The rise of the HSP may had been based on of the HOS battlefield successes, but after that, HSP never became a political option worth much attention.

In the mid-1990s, Mladen Schwartz, a Croat of Jewish descent, organized the New Croatian Right. The party and its leader were openly antisemitic. In 1995, the party distributed flyers with "Jews out" written on them. The military prosecutor filed a criminal complaint against spreading racial, national, and religious hate (Zlatković Winter, 1995, p. 339). Although very vocal, this extreme political party never participated remained marginal and ineffective on Croatian political scene.

\section{Franjo Tuđman on the Holocaust}

During his tenure in office, F. Tuđman apologized for the deeds of the NDH. In March 1994, he bestowed the Order of the Prince Trpimir, a high Croatian decoration, to Branko Lustig, a Croatian film director and Holocaust survivor. At the ceremony, he apologized to Lustig and to "all the members of the Jewish Community for those who participated in the Holocaust and the implementation of Nazi-Fascist racist crimes of the NDH” (M. Tuđman, 2015c, pp. 109-110).

F. Tuđman contributed to Holocaust research. According to Julienne Eden Bušić, in 1995 F. Tuđman approved that Croatia open the World War II archives to the US Holocaust Memorial Museum, the first post-communist country to do so. Croatian representatives delivered to the Museum the donation of books and documents related to the Holocaust in a special ceremony (Radoš, 2005, p. 147).

\section{Jasenovac memorial park as symbol of Croat reconciliation}

F. Tuđman planned to renovate the Jasenovac Memorial Park as a memorial to victims of the Croatian War of Independence; it was among his most criticized ideas. He announced it at the Second General Conference of HDZ October 15-16, 1993 (Jureško, 1993, pp. 2-3) and repeated it in 1996 in the "State of the Nation" report. The idea was to commemorate the victims of communism along with the existing monuments to the victims of fascism by "transferring the remains and bones from the discovered caves" and victims of the Croatian War of Independence "so that, for everyone killed in the struggle for a free Croatia, we would set up a memorial stone (or a cross) with their name. In this way, we would pay respect to all the victims and that would be a testimony of reconciliation and truth about all those who perished on their way to an independent and sovereign Croatian state” (Izvješće, 1996, p. 42).

The idea symbolized F. Tuđman's policy of national reconciliation. However, S. Goldstein, whose cousins and in-laws perished in Jasenovac, reacted negatively. S. Goldstein sent an open letter to F. Tuđman, warning him of legal action if he did not abandon the plan (S. Goldstein, 1996, p. 4). Others in Croatia also reacted sharply, for example the Union of Antifascist Fighters of Croatia (Šimić, 1996, p. 3) and some Croatian media (Čulić, 1996, pp. 4-6). The Croatian Bishop's Conference expressed understanding of the plan, but warned that some would see in it "an intention to relativize the significance of Jasenovac 
victims and diminishing the guilt for Jasenovac camp" harming Croatia's reputation (M. Tuđman, 2015d, pp. 168-169). Reactions from abroad were also negative, including those of the Chairman of the United States Holocaust Memorial Council (M. Tuđman, 2015d, pp. 109-110); Warren Christopher, US Secretary of State (Christopher o Jasenovcu, 1996, p. 3); Walter Reich, director of the US Holocaust Memorial Museum (Reich, 1996); fifty-two US congressmen (M. Tuđman, 2015d, pp. 148-151), and Tommy Baer, president of Jewish organization B’nai B’rith (M. Tuđman, 2015d, p. 161).

Mostly former communists referred to the idea as "mixing the bones." In an interview F. Tuđman explained that "if we want reconciliation, if we came with it to Croatian liberty and democracy, then precisely for that we have to [do it] even in Jasenovac, not to (...) mix the bones of the victims of fascism and communism, but to determine exactly how many people were killed as victims of the NDH, fascism and racial laws, and how many as victims of communism, and for that purpose we would transfer the bones that we have out of the caves to that place” (Hina, 1996, pp. 19-23).

F. Tuđman may have been inspired by the aftermath of the battle of Gettysburg in the American Civil War when the fallen from both sides were interred together as were the fallen in the Spanish Civil War. The latter was initiated by the Spanish dictator Francisco Franco; the similarity of the idea to Franco's likely contributed to the negative reaction to F. Tuđman’s (Hina, 1996, pp. 19-23).

F. Tuđman envisioned three memorial areas, one for Jewish victims of the Ustasha regime, one for Croat victims of the communist regime 1945-1948, and one for Croatian soldiers fallen in the War of Independence (M. Tuđman, 2015d, pp. 143-145, 148-151). The latter would be reminiscent of the Arlington National Cemetery in the USA. Within the memorial to Jews, F. Tuđman intended to build "a small synagogue or another small religious monument." The idea of "mixing bones" was strongly refuted by the President's Office statement (M. Tuđman, 2015d, pp. 143-145, 148-151). Nevertheless, the idea of "mixed bones" even symbolically was also vehemently rejected. In the end, F. Tuđman gave up (M. Tuđman, 2015d, p. 184). According to Mate Granić, the then minister of foreign affairs, F. Tuđman gave up so as not to deteriorate relations with the USA (Granić, 2005, p. 144).

\section{Croatian Jewish community in the 1990 s}

Perhaps the best way to analyze the attitude of F. Tuđman and the Croatian leadership towards Jews is to examine the position of the Jewish community and the activity of prominent Jews in Croatia. The issue must be considered within the context of the fall of communism. Democratic changes allowed freedom of expression of national affiliation and religious sentiments ushering a new period for the Croatian Jewish community. Some Jews participated in the democratic changes actively, such as journalist and publisher Slavko Goldstein, the co-founder of the Hrvatska socijalno-liberalna stranka (Croatian Social Liberal Party, HSLS), the first opposition to Croatian communists.

Within this new political and social framework, Jews were mentioned by name in the Croatian Constitution of December 1990 that defines Croatia as "the nation state of the 
Croat nation and the state of members of other nations and minorities, who are its citizens: Serbs, Muslims, Slovenians, Czechs, Slovaks, Italians, Hungarians, Jews and others, who are guaranteed equality with citizens of Croat nationality and the exercise of their national rights in compliance with the democratic norms of the United Nations and the countries of the free world” (Ustav Republike Hrvatske, 1990).

\section{Jewish community in Republic of Croatia}

The Holidays and Work-Free Days Law of 1991 stipulates that Jews have the right of paid absence from work on Yom Kippur and Rosh Hashanah (Zakon o blagdanima, 1991; Zakon o blagdanima, spomendanu i neradnim danima, 1996). With the breakdown of Yugoslavia and with Croatia acquiring independence, the Jewish community in Croatia could communicate and cooperate with international Jewish organizations directly, without any government interference (S. Goldstein, 1998, p. 24).

The Coordination of Jewish Communities in Croatia, led by Ognjen Kraus, was established on January 25, 1992. The Coordination consisted of nine communities: Čakovec, Daruvar, Dubrovnik, Osijek, Rijeka, Slavonski Brod, Split, Virovitica and Zagreb. In 1999, Koprivnica joined the Coordination (Zlatković Winter, 1995, p. 332). Also, the Union of Jewish Youth Organizations and Union of Jewish Women were formed (Švob, Brčić \& Podgorelec, 1994, pp. 80-81). Government representatives are often present at Jewish commemorations (Hina, 1993, p. 3; Živaković-Kerže, 2006, p. 222). After the fall of communism, public interest in Jewish community increased significantly. Some media became interested in Jewish affairs, spiritual values and heritage. For example, Radio station "Baranja" dedicated a program to Judaism, Jewish history and culture (Živaković-Kerže, 2006, p. 224).

\section{The Greater-Serbian aggression and propaganda against Croatia}

The Greater-Serbian aggression on Croatia lasted from mid-1991 to August 1995. Disregarding the laws and customs of war, the Serbian para-military and military organisations occupied almost one third of Croatia, inflicted large destruction, which resulted in the torture and death of Croatian and other non-Serb civilians (Perković Paloš, 2020, pp. 267-294). The aggression included Serbian propaganda against Croatia, aiming to portray the democratically elected Croatian authorities as antisemitic and Jews as endangered by authorities and the military (Figure 1).

\section{Serbian attacks on Jewish property in Croatia: a method of special warfare}

On August 19, 1991 a terrorist group set up and activated explosive devices at the Jewish section of Mirogoj, the central Zagreb cemetery, and at the gate of the Jewish Community Center in Zagreb (Napad na Židovsku općinu, 1991, p. 4). Two perpetrators admitted that the attack was undertaken by the Yugoslav military counterintelligence. Radenko Radojčić, one of the two, described the action in detail in his statement to the Ministry of Interior of the Republic of Croatia in 1994 (Radojčić, 2009, pp. 78-81). The other, Mustafa Čandić confirmed his participation in the action at the trial of Slobodan Milošević before the International Criminal Tribunal for the former Yugoslavia (ICTY) in 2002 (ICTY, 2002). The 
terrorist action was a part of the Serbian special war against Croatia aimed to damage relations of the Croatian leadership and Jewish community and portray Croatian authorities as antisemites (ICTY, 2002, pp. 12734-12735; Cohen, 1997, p. 186; Radoš, 2005, pp. 143-144).

Croatian press extensively reported on the attack. Government and political parties condemned the terrorists and expressed sympathy to the members of Jewish community (Hina, 1991, p. 4; Gregurić, 1998, p. 51). The next day, on invitation by Croatian Democratic Party, at the time part of the Croatian Democratic Unity Government, citizens, public figures and members of government and opposition gathered on the central Ban Jelačić square in Zagreb expressing solidarity with and support for fellow Jews (Solidarnost sa Židovima, 1991, p. 4). Many walked from the Mirogoj cemetery to the Jewish Community Center at the corner of Palmotićeva and Amruševa Streets (Ni mrtvima mir, 1991, p. 4). Slavko Goldstein (1998, p. 25) reported that the government paid for renovation of the damaged building.

The terrorist act by the Yugoslav military counterintelligence service provoked strong reactions of the international community and damaged Croatia's image. On the day of explosion, the Inter-Parliamentary Council of the House of Commons of the British Parliament sent a letter to F. Tuđman, expressing concern about the event and seeking "assurances" from the Croatian president that he would protect the Jewish community in Croatia (M. Tuđman, 2015e, p. 265). F. Tuđman responded that it was a "deliberate provocation" which aimed to accuse the Croatian leadership and people of antisemitism and accordingly damage relations of the Jewish community and Croatian leadership. F. Tuđman emphasized that the Croatian government, including all political parties and himself personally, had "protested against the criminal act," noting that the city of Zagreb and Republic of Croatia would help the Jewish community to repair the damage. He also informed them of his intent to rebuild the synagogue destroyed in World War II (M. Tuđman, 2015a, p. 266).

\section{Reactions of the International Council of Christians and Jews}

In the first half of November 1991, Yugoslav Ministry of Foreign Affairs passed to the Croatian government a letter from Sigmund Sternberg, chairman of the Executive Board of the International Council of Christians and Jews. The letter stated there was an increase of antisemitism in Yugoslavia and especially in Croatia; Sternberg expressed concern for the position of Jews. He mentioned the explosion at the Jewish sites in Zagreb in support of his claims. He also mentioned that Jewish Community leaders received death threats, and the alleged "denial of the Holocaust" (Sternberg, 1991). With the letter he enclosed the October 21 article by Phil Davidson of the London Independent that accuses Croatian leadership of increased antisemitism. Davidson wrote from the Serbian town of Kragujevac about a "crisis meeting" held by Jewish leaders in Belgrade where they unanimously expressed concern because of the "parallels between the Nazi and pro-Nazi massacres of 50 years ago and the unease of Jews in Croatia under the strongly nationalist regime in the breakaway republic today" (Davidson, 1991). The author of the article was obviously influenced by Klara Mandić, a Serbian woman of Jewish origin and the secretary of the Society of Serbian-Jewish Friendship, founded in Belgrade in 1987 under the patronage of the Serbian leadership (Cohen, 1997, pp. 173-174). Davidson took Mandić at her word that 
"those in power in Croatia now are largely the same as during the Nazi era" and "in some cases, they are exactly the same people, now in their seventies and back from exile under the Communists. In other cases, they are children of the Ustashe.” He claimed F. Tuđman would not dare touch the Jews now when they have their own state and that F. Tuđman "has prepared an atmosphere similar to that at the start of the Second World War and the fact is that many of the Croatian groups are out of his control" (Davidson, 1991). Davidson provided no evidence for his claims.

Three days after the arrival of the Sternberg letter, Lea Bauman, member of the Zagreb Jewish Community and official in Croatian Ministry of Information refuted Davidson's claims: "As a Jew, I am afraid of Serbian aggression against Croatia, not of Croats in Croatia," and continued that "it does not matter if one is Croatian, Hungarian, Czech or Jewish, as long as he is treading on Croatian soil where the Serbian army wishes to plant the garden of Greater Serbia” (Bauman, 1991). As Davidson wrote the article in Serbia, Bauman invited him to Croatia to talk to Darko Fischer, the leader of Jewish Community in Osijek, whose building had been bombed by the Yugoslav army (Bauman, 1991). She implied that Davidson was unfamiliar with the circumstances of Jews in Croatia exposed to Serbian aggression. Nevertheless, accusations continued; examples are presented in Table 2.

Table 2. Accusations of the Croatian leadership and Croatian military forces of antisemitism (1991-1992)

$\begin{array}{llll}\text { Author } & \text { Accusation } & \text { Argument } & \text { Evidence } \\ \begin{array}{l}\text { Sternberg, S. } \\ \text { (1991) }\end{array} & \begin{array}{l}\text { Antisemitism in Croatia in } \\ \text { general. }\end{array} & \begin{array}{l}\text { 1. Explosion in front of the Jewish } \\ \text { Community in Zagreb. } \\ \text { 2. Death threats to the leaders of the } \\ \text { Jewish Community. }\end{array} & \begin{array}{l}\text { Sternberg did not pro- } \\ \text { vide any evidence. }\end{array} \\ \text { Davidson, P. (1991) } & \begin{array}{l}\text { Antisemitism in Croatian lead- } \\ \text { ership. }\end{array} & \begin{array}{l}\text { Comparison of democratically elected } \\ \text { Croatian leadership from the 1990s to the } \\ \text { Nazis. }\end{array} & \begin{array}{l}\text { Davidson did not pro- } \\ \text { vide any evidence. }\end{array} \\ \begin{array}{l}\text { Mandić, K. (1992) } \\ \text { (from: Cohen, P, }\end{array} & \begin{array}{l}\text { Croatian soldiers killed an elder- } \\ \text { l992) }\end{array} & \begin{array}{l}\text { Presentation of the victim as "the first } \\ \text { Jewish victim" of war. }\end{array} & \begin{array}{l}\text { Mandić forged evi- } \\ \text { dence. }\end{array}\end{array}$

\section{Klara Mandić and propaganda: Croatian war victim presented as Jewish war victim}

The Serbian lobby managed to create a parallel between Jews and Serbs as peoples who had undergone genocide and who, again, were endangered by Croats (Cohen, 1992). Among the influential members of the Society of Serbian-Jewish Friendship was aforementioned Klara Mandić. Her propaganda impacted international Jewish organizations and damaged Croatia's image. On February 20, 1992 Mandić gave a lecture to the Jewish student organization Hillel House at George Washington University in Washington, D.C. She claimed to the American press that in September 1991 "Croatian extremists" (referring to Croatian soldiers) had killed Ankica Konjuh, an elderly Jewish woman. She presented her murder as "evidence" of antisemitism asking: "Who among us will be next?" (Cohen, 1992; Cohen, 1997, p. 185) implying that Jews and Serbs were unsafe in Croatia. It is noteworthy that Ankica Konjuh was a Croat among 240 civilians liquidated by Serbian military in the Croatian town of Petrinja occupied on September 21, 1992 (Horvatić \& Krpan, 2013, p. 210; Cohen, 1997, pp. 185, 270-271). In December 1991, the Federation of Jewish Communities of Yugoslavia wrote to Mandić requesting she not speak about Ankica Konjuh as "the first Jewish victim of war,” but to no avail (Cohen, 1992). 


\section{Croatian Jews in the War of independence}

In the early 1990s, Jews found themselves in the same situation as Croats and other nonSerbs in Croatia, endangered by Serbian aggression and experiencing all of the war. Some prominent Jews compared the aggression to the Nazis, advocated for international recognition of Croatia and provided significant humanitarian help (see below).

\section{Jews endangered by Serbian aggression}

Jews were endangered not as a specific target, but just as other non-Serb population. Some Croatian Jews sent their children to Israel or the USA (Živaković-Kerže, 2006, pp. 214-215). Jews in Osijek suffered a particularly difficult fate, but the same as the rest of the city under relentless shelling by Yugoslav military and Serbian paramilitaries (Bauman, 1991). The Jewish Community Center in Osijek was situated not far from Yugoslav Army barracks wherefrom it was often the targeted by grenades. The hardest attack happened on September 15, 1991 when two shells broke all windows (Živaković-Kerže, 2006, pp. 215216). According to Darko Fischer, "the even stronger destruction of the city [Osijek] and suffering of civilians" prompted an appeal by the Osijek Jewish community to all Jewish organizations in the former Yugoslavia "to use their influence and work on a peaceful resolution of the conflict.” The appeal stated:

"We think that all the members of the Jewish community in Yugoslavia, all the Jews in the diaspora and in Israel should know what is happening in Osijek and in similar towns. People who have carried in their genes three thousand years of pain and suffering should raise their voice and use its influence to break the foolishness of war.”

The appeal had a great response. Fischer was invited to a press-conference and to a live broadcast on Croatian Television in Osijek. Srđan Matić, secretary of the Jewish Community of Zagreb, translated the appeal into English and sent it to Jewish magazines that later published it (Živaković-Kerže, 2006, pp. 215-216). Fischer also testified to the difficult conditions related to the severe damages in Osijek during 1991 and 1992. His testimony was published in the Zagreb Bulletin. Fischer stated that:

"During World War II we were robbed, persecuted, forced into concentration camps, tortured and killed. Those fortunate few who escaped were without any livelihood, any clothes, no firewood and in constant danger of physical extermination. Besides, we were exposed to the fear of war, gunfire, shelling, staying in shelters. Now we are endangered equally or even less than our fellow citizens. We are exposed to war damage, grenades, bombs, destruction and burning down our apartments, to sniper fire. Like in 1941, within a few seconds we could be left without everything we have been building for years, without an apartment, job, possibility of survival. But that is not the worst of it. We can lose our children, relatives, and friends. We can be wounded and maimed" (Živaković-Kerže, 2006, pp. 214-215).

In conversation with some foreign journalists, the Jewish Community of Osijek helped change the widespread perception of the "Jews' endangerment in Croatia." In mid-October 1991, Itai Anghel, an Israeli journalist, visited Osijek and recorded an interview with 
Fischer. The interview was broadcasted on Israeli radio and some of it was published in the Israeli newspaper Ha'arec (Živaković-Kerže, 2006, pp. 216-217). The later Ha'arec correspondent in Budapest Yehuda Lahav later came to Osijek and told Fischer that the article on Jews in Osijek had some readers opine that it had been "written under pressure" to portray the position of Jews in Croatia as better than it actually was. Fischer responded that the article indeed had been written under pressure, "but the pressure came from the explosions of the enemy bombs” (Živaković-Kerže, 2006, p. 218).

In the early 1992, Fischer and Matić traveled to Washington to provide statements to the American Senate on the position of Jews and the human rights in Croatia. The aim was to reduce the impact of Serbian propaganda and Klara Mandić on the "endangered Jews in Croatia.” Matić and Fischer had talks with White House officials, visited the B'nai B'rit headquarters in Washington and answered questions by the Voice of America and Washington Post. In New York they visited the association of Jews from the former Yugoslavia and in conversation with their representative Mary Levin tried to improve the image of Croatia (Živaković-Kerže, 2006, p. 221).

\section{Croatian Jews advocating for recognition of Croatia}

Serbia inherited the diplomatic network of the former Yugoslavia and its strong lobby while Croatian diplomacy was in its infancy. For that reason, Croatian leadership seriously counted on Jews and their community to help Croatia on its path to independence and international recognition. According to the Croatian deputy prime minister Zdravko Tomac, among the basic goals of Croatian foreign policy was to establish contacts with the "Jewish lobbies of the world" (Tomac, 2004, 163).

The Croatian government gained significant help from the Zagreb Community and its president Nenad Porges, a prominent entrepreneur and HDZ member. Porges's paternal grandparents perished in the Holocaust, while his father was spared as an essential worker for the Third Reich. Porges had numerous functions in the Croatian leadership. From 1993 to 1995 he was an advisor to prime minister Nikica Valentić, from 1995 to 1997 Deputy Chief of Mission at the Croatian embassy in Washington, and from 1997 to 2000 Minister of Economy.

Porges's highly visible contribution to wartime Croatia was the "Appeal to our Jewish Brothers and Sisters," an open letter written in the name of Jewish communities in Croatia. The October 7, 1991 letter to the World Jewish Congress, European Jewish Congress and other international Jewish organizations advocated for the international recognition of Croatia and support for the Croatian War of Independence. Porges stated that Croatian leadership was not antisemitic, Jews were equal in Croatia in national, religious and all other aspects, that Croatian government publicly denounced all neofascist ideologies and "had decided to take all the necessary legal steps to prevent the spread of such threats." He also claimed that Yugoslav People's Army had carried out an aggression against Croatia and briefly described their methods of warfare, such as killing civilians regardless of nationality, destroying hospitals, kindergartens, nursing homes and schools and bombing hundreds of cultural, historical and religious monuments, among them Jewish monuments. He singled out the bombing of the Jewish Community Center and cemetery in Zagreb and 
damage to the medieval synagogue in Dubrovnik, the second oldest in Europe. Porges also asserted that the Jewish Community in Zagreb received support from the Croatian government after the terrorist attack in August 1991 (Porges, 1991; Oraić Tolić, 1992, p. 394).

\section{Jewish humanitarians during the War}

The Jewish community and some of its members provided different kinds of humanitarian aid. Entrepreneur Jakov Bienenfeld, a Council member of the Zagreb Community, came from a family that lost some forty members during NDH. Jakov's father Zlatko Bienenfeld was a member of the WWII Partisan resistance and a professor of chemistry at the Military Academy of the Yugoslav People's Army with the rank of colonel. He was a colleague and a family friend of Franjo Tuđman for some time in Yugoslavia. In the early 1990s, President Tuđman promoted Professor Bienenfeld into the rank of Major General of the Croatian army in reserve and elected him as the adviser to the Croatian defense minister Gojko Šušak (Tko je bio Jakov Bienenfeld, 2016). Jakov Bienenfeld provided humanitarian help to Vukovar, the easternmost Croatian city that suffered monumental destruction during three-month siege (Marijan, 2013; Tko je bio Jakov Bienenfeld, 2016). After the fall of the city in November 1991, Bienenfeld participated in the preparation of plans for a prisoner-of-war exchange. In December 1991 he made the connection with Belgrade through Paris and contributed to the liberation of one group of prisoners, including Vesna Bosanac and Juraj Njavro, physicians from the Vukovar hospital (Tko je bio Jakov Bienenfeld, 2016). Jakov Bienenfeld had a positive attitude concerning F. Tuđman, did not see him an antisemite, even mentioned once that in $1992 \mathrm{~F}$. Tuđman proposed to him to rebuild the Zagreb synagogue, which Jakov refused: "I answered, Mr. President, I think that it would be stupid to build a synagogue. I do not want to build a monument after five thousand churches and ten thousand schools had been destroyed in Croatia" during the War of Independence” (Držić, 2012).

The Zagreb Community and some its members took part in humanitarian aid to Dubrovnik, the southernmost Croatian city and the UNESCO-designated world heritage site. Dubrovnik was cut off from the rest of Croatia by land, while the Yugoslav Navy blockaded the city from the sea (Nazor, 2011, p. 231). Consequently, the city could not be resupplied with water, electricity, food and medicine. At the end of October 1991, a civic initiative organized a supply convoy named Libertas. The convoy included forty ferryboats that broke through the naval blockade and brought food, water and medical supplies. Among the co-organizers of the Convoy was Slobodan Lang, a physician of Jewish origin and special advisor for humanitarian affairs to President Tuđman; Land's paternal grandparents were killed in the Holocaust. After the arrival of the convoy, Lang opened a Convoy Libertas Office in Dubrovnik which was "the only public place for gathering in Dubrovnik," as well as "a place for coordination, events, planning and informing” (Lang, 1997, p. 114). Lang stayed in Dubrovnik during the most brutal attack on the old town in December 1991, where he was writing a journal describing the aggression, the everyday struggle of civilians, and humanitarian actions:

"This is a war in which all crosses were intentionally shot, in which a church was intentionally shot, and a maternity hospital, and a home. Not because they were 
monuments, but because a pregnant woman could hide there. And a new-born baby. And a sick man who would want to hide there. And a priest who would provide support. This is why it was destroyed. To destroy these people” (Lang, 1997, p. 10).

Lang even compared the citizens of Dubrovnik who had to leave their homes to Jews in World War II: "They sailed, fleeing like Jews were fleeing once in the face of fascism" (Lang, 1997, p. 13). Later he sent an SOS message to the world comparing the JNA and Serbian and Montenegrin troops to the Nazis:

"Reject the successors of Nazism, reject those who ignited Dubrovnik as the ovens of Auschwitz were ignited, that burn Dubrovnik like all of those in German camps of were burnt. Reject Hitler's successors ...” (Lang, 1997, p. 73).

Lang documented the shelling of the synagogue and Jewish cemetery in Dubrovnik in early November 1991 (Lang, 1997, p. 19). Along with prominent citizens of Dubrovnik, Lang appealed for help from international humanitarian organizations to preserve the lives of civilians and cultural heritage of the city (Lang, 1997, pp. 124-127). During the war, Lang organized or helped found several humanitarian organizations. After Operation Storm in 1995, which liberated most of the occupied Croatian territory and ended the war, Lang co-organized "welfare centers" in some liberated Croatian towns "to protect the old and infirm who remained in their homes in wooded areas." Serbian civilians en route to Serbia were provided assistance as well (Lang et al., 1997, p. 4).

In the course of 1992, the Community of Zagreb provided financial help to the governmental Office of Refugee Affairs, to Catholic Caritas of the Bishop's Conference and to Merhamet of the Islamic community (Zlatković Winter, 1995, p. 337; Švob, Brčić \& Podgorelec, 1994, p. 77). Jewish communities of Zagreb and Split contributed the most to the care of refugees with support from international Jewish humanitarian organizations. Some five hundred people, one third Jewish, left Sarajevo in four convoys of eight buses and a numerous automobiles (Zlatković Winter, 1995, p. 338). From the beginning of the war in Bosnia and Herzegovina, eleven hundred refugees, members of the Jewish community, mostly from Sarajevo, Zenica, Mostar, Tuzla and Jablanica, came to Croatia. About eight hundred of them left for other countries, most to Israel (Zlatković Winter, 1995, p. 338).

Kornel Neuman, an alumnus of the Jewish school in Osijek, founded the association Pro Croatia in Bern, Switzerland, where he lived. He collected medical aid and drove it to the Hungarian town of Pécs where he was welcomed by a team from the Croatian Television studio in Osijek, a representative of the Osijek Red Cross from Osijek and president of the Osijek Jewish Community. The package was delivered to the Red Cross office in Osijek and a report on that aid was broadcast on Croatian Television (Živaković-Kerže, 2006, p. 219).

\section{Jews in Croatian political leadership}

Mihael (Mišo) Montiljo worked in the Croatian Ministry of Foreign Affairs. Montiljo survived the Holocaust by escaping from the Sarajevo camp where he had been imprisoned with his family and eventually joined the Partisans. Montiljo had thirty years of experience in government of the Socialist Republic of Croatia. From 1990 to 1992 he worked as 
assistant to the Croatian Foreign Minister. On the initiative of the then minister of foreign affairs Davorin Rudolf in the first half of 1991, Montiljo went to Israel to improve relations with Israel. Three years later he founded the Croatian-Israeli Society to promote cooperation between the two countries (Rudolf, 1999, p. 84; Rudolf, personal communication, February 7, 2014). In October 1991 Montiljo went to Australia where he met with Isi Leibler, cochairman of the Executive Board of the World Jewish Congress. Montiljo informed Leibler that the new Croatian authorities cooperated sucessfully with the Jewish community in Croatia, for example in crafting the Law on Religious Holy Days. He also mentioned the plans for rebuilding the Zagreb synagogue and the building of the Jewish cultural centre. Montiljo also challenged the propaganda of Klara Mandić (Židovi pridonose slobodi Hrvatske, 1991, p. 6). In December 1991, Montiljo visited Australia again, where he met with the representatives of the Jewish community in Canberra. He introduced them to Porges's "Appeal" and to "the favorable position of Jews" in Croatia emphasizing the first time mention of Jews in Croatian constitution (Šmidt, 1991, p. 8).

At the beginning of 1992, Slobodan Lang, president of the Croatian-American Society, member of Parliament and ambassador in the Ministry of foreign affairs, in numerous conversations informed the Jewish communities in New York, San Francisco, Atlanta and Washington of Serbian propaganda and the situation in Croatia (Američki Židovi i mi, 1992, p. 13).

Davor Štern, another prominent entrepreneur and self-described "half-Jew" (Radoš, 2005, p. 146), was the head representative of Croatian oil company INA-Industrija nafte in the Soviet Union in the 1980s. In 1994, F. Tuđman called him to return to Croatia where Štern became a member of HDZ. He became deputy minister and then minister of economy from 1995 to 1997. Štern was active in Croatian diplomacy, and contributed to the establishment of diplomatic relations between Croatia and Israel in 1997. He claims that F. Tuđman was not an antisemite and that had "a great love for Judaism” (Radoš, 2005, p. 146).

Some regard the Jews in Croatian political life as "court Jews". One of them is journalist Ljubo Ruben Weiss who had also lost family members in the Holocaust. In 1991, during aggression on Croatia, he emigrated to Austria (Margetić, 2013).

\section{Relations of Croatia and Israel}

Influence of the Serbian lobby in Israel was felt even after the State of Israel, by American initiative, recognized Croatia in April 1992. Hebrew University of Jerusalem professor Igor Primorac (2000, p. 13) claimed that from the beginning of the dissolution of Yugoslavia Israeli authorities took the "Serbian side" and that Serbian lobby in Israel was very aggressive. Consequently, Israelis interpreted Serbian aggression in Croatia as a consequence of World War II, so up until 1995 they did not condemn Serbia for its war crimes.

F. Tuđman's associates claimed that the Croatian president took decisive steps to bridge the gap between Croatia and Israel to improve the international position of Croatia. In May 1992, he sent congratulations to the Israeli president on the occasion of Israeli Independence Day (M. Tuđman, 2015a, p. 297). F. Tuđman desired a speedy establishment 
of diplomatic relations with Israel (M. Tuđman, 2015b, pp. 322-325) and expressed the wish to visit Israel and personally apologize for the Ustasha crimes against Jews in the NDH (M. Tuđman, 2015c, pp. 363-364). Štern stated that during his official visit to Israel in 1997, in the Israeli Ministry of Foreign Affairs they were still speaking about the "chauvinist and nationalist" Croatian government and considered F. Tuđman a "hater of Jews." Štern claimed that those opinions had been formed based on F. Tuđman's Wastelands so it seemed that the opinion of F. Tuđman and his government at the time had not changed, even though the controversial quotes had been taken out of the book. Nevertheless, Croatia and Israel got closer to establishing, diplomatic relations.

Discussions about the establishing of diplomatic relations were initiated in August 1997 (Radoš, 2005, pp. 149-150) and concluded a year later in New York (Malenica, 1997, p. 48). Resistance to F. Tuđman's visit to Israel, however, was still strong, so instead of him, Minister of Foreign Affairs Mate Granić went on an official visit (Radoš, 2005, pp. 150-151). Despite the establishment of diplomatic relations, F. Tuđman's apologies and the removal of the controversial quotes from his book, one influential American web site called him a racist and antisemite when reporting on his death in December 1999 (Leicht \& Schwarz, 1999).

\section{Conclusion}

Interpretations, particularly in international circles, of F. Tuđman's 1989 book Wastelands of Historical Reality and statements from the 1990s are at odds with his de facto relation with Jews and his policy towards Jewish community in Croatia and the State of Israel. Most authors who wrote about F. Tuđman, his opinion about the Holocaust and his attitude towards Jews appear not to have used primary sources, but uncritically relied on questionably and, possibly, tendentiously translated excerpts of F. Tuđman's book. Authors who alleged that F. Tuđman's statements from 1990 attempted to rehabilitate the Ustasha regime ignored the plethora of speeches and writings where he was highly positive towards the Partisan resistance to occupiers in World War II (in which he himself actively participated) and in which he condemned the Ustasha crimes. This attitude was incorporated into the Croatian constitution and formed a significant part of F. Tuđman's personal history. Whatever the true aim of these authors, they neither contributed to scholarly historiography nor to the establishment of justice in the afterwar period.

In distinction to the reverberations of the Serbian propaganda, the Jewish community in Croatia was endangered by the JNA and Serbian paramilitaries, not by Croats. Prominent Croatian Jews advocated for international recognition of Croatia, refuted claims of antisemitic Croatian leadership, participated in Croatian leadership and provided humanitarian help to their country during Serbian aggression. One can argue that the significance and scope of contribution by Croatian Jews to the establishment of Republic of Croatia greatly surpasses the small size of their community. 
Provenance: This article is based on an earlier publication by Perković Paloš A. (2016). Je li hrvatska vlast 1990-ih bila antisemitska? Časopis za suvremenu povijest [Journal of Contemporary History], 48(2), 291-329, with the permission from Časopis za suvremenu povijest.

Peer review: Externally peer reviewed.

Received: 3 January 2020 / Accepted: 11 February 2020 / Published online: 31 December 2020.

Funding: This research received no specific grant from any funding agency in public, commercial or not-for-profit sectors.

Authorship declaration: APP is the sole author of the study.

Competing interests: The author completed the ICMJE Unified Competing Interest form (available upon request from the corresponding author), and declares no conflicts of interest.

\section{ORCID}

Andrijana Perković Paloš (iD https://orcid.org/0000-0003-3048-2023

\section{References}

Američki Židovi i mi [American Jews and us]. (1992, February 8). Slobodna Dalmacija [Free Dalmatia]. Anonymous. (2007). Stipe Mesić velića NDH [Video]. Available from https://youtu.be/jLaIDT8FZHw.

Anonymous. (2013). Stjepan Mesic Sydney Australia May 1992 Dan Hrvatske Državnosti [Video]. Available from https://youtu.be/X8JFNhyl09Y.

Arendt, H. (1964). Eichman in Jerusalem. A Report on the Banality of Evil. The Viking Press. Retrieved from https://platypus1917.org/wp-content/uploads/2014/01/arendt_eichmanninjerusalem.pdf.

Arendt, H. (2015). Izvori totalitarizma [Origins of totalitarianism]. (Mirjana Paić Jurinić, Trans). Disput.

Atkins, S. E. (2009). Holocaust denial as an international movement. Praeger. Retrieved from https:// archive.org/details/HolocaustDenialAsAnInternationalMovement/mode/2up.

Bailer-Galanda, B. (1997.). 'Revisionism' in Germany and Austria: the evolution of a doctrine (pp. 1-21). Retrieved from https://www.doew.at/cms/download/12497/1_bailer_revisionism.pdf.

Banac, I. (1992). Protiv straha. Članci, izjave i javni nastupi 1987. - 1992. [Against fear. articles, statements and public appearences 1987-1992]. Slon, Grafički zavod Hrvatske.

Barić, N. (2005). Srpska pobuna u Hrvatskoj 1990-1995. [Serb Rebellion in Croatia 1990-1995]. Golden marketing-Tehnička knjiga.

Barić, N. (2007). Antifašistička borba u Drugom svjetskom ratu u političkim interpretacijama hrvatskih predsjednika 1991-2006. [Antifascist struggle during World War II in political interpretations of Croatian presidents 1991-2006]. In V. Katz (Ed.), Revizija prošlosti na prostorima bivše Jugoslavije [Revision of the past in former Yugoslavia] (pp. 211-233). Institut za istoriju. Retrieved from http://cliohipbih.ba/wp-content/uploads/2015/12/Revizija-pro\%C5\%A1losti-na-prostorimabiv\%C5\%A1e-Jugoslavije.pdf.

Barić, N. (2011). Prvi hrvatski predsjednik dr. Franjo Tuđman o jugoslavenskom predsjedniku Josipu Brozu Titu [The first Croatian president dr Franjo Tuđman on Yugoslav president Josip Broz Tito]. In V. Herman Kaurić (Ed.), Dr. Franjo Tuđman u okviru hrvatske historiografije. Zbornik radova sa znanstvenog skupa održanoga u Hrvatskom institutu za povijest u Zagrebu 10. i 11. prosinca 2009. [Dr Franjo Tuđman in Croatian historiography. Proceedings from the scientific conference held in the Croatian Institute of History in Zagreb December 10 and 11 2009] (pp. 313340). Hrvatski institut za povijest.

Bartulin, N. (2013). Honorary Aryans. National-Racial Identity and Protected Jews in the Independent State of Croatia. Palgrave Macmillan. 
Batušić, Z. (1991, September 17). Hrvatska peta kolona. [Croatian fifth column]. Danas [Today].

Bauman, L. (1991, October 24). Jews fear Serbian army, not Croats. Independent. [Letter from Croatian Government]. Ured za opće poslove Hrvatskog sabora i Vlade Republike Hrvatske [General Administration Office of the Croatian Parliament - Sabor and Croatian Government]. Zagreb, Republika Hrvatska.

Beller, S. (2007). Antisemitism. A very short introduction. Oxford University Press.

Berenbaum, M. (2020). Holocaust. Encyclopedia Britannica. Retrieved from https://www.britannica. com/event/Holocaust.

Bertoša, M. (2005). Doba kliofobije: ideološke opsjene i osobna iskustva: neke uspomene na historiografiju druge polovice prošloga stoljeća. [The age of cliophobia: ideological illusions and personal experiences: some memories on historiography of the second half of the last century]. In S. Lipovčan \& Lj. Dobrovšak (Eds.), Hrvatska historiografija XX. stoljeća. Između znanstvenih paradigmi $i$ ideoloških zahtjeva [Croatian historiography of the 20th century. Between scientific paradigms and ideological requirements] (pp. 99-109). Institut društvenih znanosti Ivo Pilar.

Birin, A. (2005). Ideološke politizacije i najnovija hrvatska historiografija (1989. - 2002.) [Ideological politizations and the latest Croatian historiography (1989-2002)]. In S. Lipovčan \& Lj. Dobrovšak (Eds.), Hrvatska historiografija XX. stoljeća. Između znanstvenih paradigmi i ideoloških zahtjeva [Croatian historiography of the 20th century. Between scientific paradigms and ideological requirements] (pp. 33-55). Institut društvenih znanosti Ivo Pilar.

Birnbaum, S. (1993, April 22). Holocaust Museum is under fire for inviting Croatian President. JTA Daily News Bulletin. Retrieved from http://pdfs.jta.org/1993/1993-04-22_074.pdf.

Boljkovac, J. (2009). “Istina mora izaći van...”. Sjećanja i zapisi prvog ministra unutarnjih poslova neovisne Hrvatske. ["The truth must come out...” Memories and notes of the first Interior minister of independent Croatia]. Golden marketin - Tehnička knjiga.

Butković, D. (1991, October 31). Paraga je dobar dečko. [Paraga is a good guy]. Slobodni tjednik. [Free Weekly].

Christopher o Jasenovcu [Christopher on Jasenovac]. (1996, April 1). Feral Tribune.

Ciliga, A. (1978). Sam kroz Europu u ratu (1939.-1945.). [Alone through Europe in War (1939-1945)]. Na pragu sutrašnjice.

Cipek, T. (2007). Politike povijesti u Republici Hrvatskoj: Od 'puška puče’ do 'Hristos se rodi' [The politics of history in the Republic of Croatia] In T. Cipek \& O. Milosavljević (Eds.), Kultura sjećanja 1918. Povijesni lomovi i svladavanje prošlosti [The culture of memory 1918. Historical fractions and overcoming the past] (pp. 13-26). Disput.

Cipek, T. (2011). Povijest uzvraća udarac: Nacija i demokratska legitimacija [History strikes back: nation and democratic legitimation]. In T. Cipek (Ed.), Kultura sjećanja 1991. Povijesni lomovi $i$ svladavanje prošlosti [The culture of memory 1991. Historical fractions and overcoming the past] (pp. 13-27). Disput.

Cohen, P. J. (1992). Serbian antisemitism and exploitation of the Holocaust as propaganda. Retrieved from https://web.archive.org/web/20160305140651/http://www.slobodanpraljak.com/ MATERIJALI/RATNI\%20DOKUMENTI/RATNA\%20HUMANITARNA\%20DJELATNOST/34.pdf

Cohen, P. J. (1997). Tajni rat Srbije. Propaganda i manipuliranje poviješću. [Serbia's secret war: propaganda and the deceit of history]. Ceres.

Čulić, M. (1996, April 29). Kosti u mikseru [Bones in the mixer]. Feral Tribune.

Čulić, M. (1999). Tuđman. Anatomija neprosvijećenog apsolutizma. [Tuđman. An anatomy of unenlightened absolutism]. Feral Tribune.

Čulić, M. (2014). Tuđman i poslije Tuđmana. [Tuđman and after Tuđman]. Novi liber.

Davidson, P. (1991, October 21). War raises old anxieties for Croatian Jews. Independent. Ured za opće poslove Hrvatskog sabora i Vlade Republike Hrvatske [General Administration Office of the Croatian Parliament - Sabor and Croatian Government]. Zagreb, Republika Hrvatska.

Držić, T. (2012, March 4). Jakov Bienenfeld: O Židovima i hrvatskom ‘istočnom’ grijehu [Jakov Bienenfeld: On Jews and Croatian 'original' sin]. Hrvatski tjednik [Croatian Weekley]. Retrieved from http://www.hkv.hr/hrvatski-tjednik/10849-jakov-bienenfeld-hrvati-se-trebaju-prestatiispriavati.html. 
Đurašković, S. (2008). Politike povijesti: Pregled razvoja discipline u Hrvatskoj i Slovačkoj [Politics of history: an overview of development of the discipline in Croatia and Slovakia]. Politička misao [Croatian Political Science Review], 45(3-4), 201-220. Retrieved from https://hrcak.srce.hr/37885.

Eaglestone, R. (2001). Postmodernizam i poricanje holokausta. [Postmodernism and Holocaust denial]. Naklada Jesenski i Turk.

Fox, T. C. (2004). The Holocaust under communism. In D. Stone (Ed.), The Historiography of the Holocaust (pp. 420-439). Palgrave Macmillan.

Geiger, V. (2020). Pitanje broja žrtava logora Jasenovac u hrvatskoj i srpskoj historiografiji, publicistici i javnosti nakon raspada SFR Jugoslavije - činjenice, kontroverze i manipulacije. [The Issue of the Number of Jasenovac Camp Victims in Croatian and Serbian Historiography, Opinion Journalism, and Public Discourse after the Disintegration of the Socialist Federal Republic of Yugoslavia - Facts, Controversies, and Manipulations]. Časopis za suvremenu povijest [Journal of Contemporary History], 52(2), 517-587. doi: 10.22586/csp.v52i2.11253.

Gerstenfeld, M. (2009). The Abuse of Holocaust memory. Distortions and responses. Jerusalem Center for Public Affairs, Institute for Global Jewish Affairs. Retrieved from http://jcpa.org/text/ holocaustabuse.pdf.

Gitman, E. (2012). Kad hrabrost prevlada. Spašavanje i preživljavanje Židova u Nezavisnoj Državi Hrvatskoj 1941. - 1945. [When courage prevailed. The rescue and survival of Jews in the Independent State of Croatia 1941-1945] (Livija Šimunić Mesić, Trans). Kršćanska sadašnjost.

Gitman, E. (2020). Alojzije Stepinac: Profile in Courage. In M. Marušić (Ed.), Croatia Past, Present and Future Perspectives (pp. 173-218). Nova Science Publishers.

Goldstein, I. (1998). Srpsko-hrvatsko pomirenje u historiografiji - pretpostavka ili posljedica političkog pomirenja? [Precondition or Consequence of the Political Reconciliation?]. Radovi Zavoda za hrvatsku povijest [Journal of the Institute of Croatian History] 31(1), 181-191.

Goldstein, I. (2002). Croatia. In Commission on Security, \& Cooperation in Europe (Ed.), Escalating Anti-Semitic Violence in Europe: Hearing Before the Commission on Security and Cooperation in Europe, One Hundred Seventh Congress, Second Session, May 22, 2002 (Vol. 4) (pp. 75-78). US Government Printing Office. Retrieved from https:/www.csce.gov/sites/helsinkicommission. house.gov/files/052202.pdf.

Goldstein, I. (2004). Židovi u Zagrebu 1918. - 1941 [Jews in Zagreb 1918-1941]. Novi liber.

Goldstein, I. (2005). Od partijnosti u doba socijalizma do revizionizma devedesetih: Ima li građanska historiografija šansu? [From Partisanship in the age of socialism to revisionism in the 90s: does the civic historiography have a chance?]. In S. Lipovčan \& Lj. Dobrovšak (Eds.), Hrvatska historiografija XX. stoljeća. Između znanstvenih paradigmi $i$ ideoloških zahtjeva [Croatian historiography of the 20th century. Between scientific paradigms and ideological requirements] (pp. 57-72). Institut društvenih znanosti Ivo Pilar.

Goldstein, I. (2008). Hrvatska 1918. - 2008 [Croatia 1918-2008]. Novi liber.

Goldstein, I. (2010). Dvadeset godina samostalne Hrvatske [Twenty years of independent Croatia]. Novi liber.

Goldstein, I., \& Goldstein, S. (2001). Holokaust u Zagrebu [The Holocaust in Zagreb]. Židovska općina: Novi liber.

Goldstein, I., \& Goldstein, S. (2011). Jasenovac i Bleiburg nisu isto [Jasenovac and Bleiburg are not the same]. Novi liber.

Goldstein, I., \& Hutinec, G. (2007). Neki aspekti revizionizma u hrvatskoj historiografiji devedesetih godina XX. stoljeća - motivi, metode i odjeci [Some aspects of revisionism in Croatian historiography of the 1990s - motives, methods and repercutions]. In V. Katz (Ed.), Revizija prošlosti na prostorima bivše Jugoslavije [Revision of the past in former Yugoslavia] (pp. 187210). Institut za istoriju. Retrieved from http://cliohipbih.ba/wp-content/uploads/2015/12/ Revizija-pro\%C5\%A1losti-na-prostorima-biv\%C5\%A1e-Jugoslavije.pdf.

Goldstein, S. (1989, November 25). Uvredljivi sudovi o Židovima i židovstvu [Offensive views on Jews and Judaism]. Vjesnik [News].

Goldstein, S. (1993). Pomirenje [Reconciliation]. Erasmus, 2, 13-18.

Goldstein, S. (1996, February 5). Otvoreno pismo predsjedniku Tuđmanu [Open letter to president Tuđman]. Feral Tribune. 
Goldstein, S. (1998). Židovska općina Zagreb od 1941. do 1997. godine [Jewish Community of Zagreb from 1941 to 1997]. In O. Kraus, (Ed.), Dva stoljeća povijesti i kulture Židova u Zagrebu i Hrvatskoj [Two centuries of Jewish history and culture in Zagreb and Croatia] (pp. 19-27). Židovska općina.

Grakalić, D. (1991, October 31). Sprečavamo libanonizaciju [We prevent lebanonization]. Nedjeljna Dalmacija [Sunday Dalmatia].

Granić, M. (2005). Vanjski poslovi. Iza kulisa politike [Foreign Affairs. Behind the scenes of politics]. Algoritam.

Gregurić, F. (1998). Vlada demokratskogjedinstva Hrvatske 1991. - 1992 [Democratic Unity Government of Croatia 1991-1992]. Naklada Zadro.

Gross, M. (1998). Ravnopravnost bez jednakovrijednosti: Prilog pitanju mentaliteta i ideologije hrvatskih cionista na početku XX. stoljeća [Equality without equality: A contribution to the question of mentality and ideology of the Croatian Zionists at the beginning of the 20th century]. In O. Kraus (Ed.), Dva stoljeća povijesti i kulture Židova u Zagrebu i Hrvatskoj [Two centuries of Jewish history and culture in Zagreb and Croatia] (pp. 106-126). Židovska općina.

Hedl, D. (1996, February 5). Mesija iskrivljenog osmijeha [A messiah with a distorted smile]. Feral Tribune.

Hilberg, R. (1973). The Destruction of the European Jews. New Viewpoints.

Hina. (1991, August 20). Žaljenje zbog zlodjela [Regret for the atrocities]. Večernji list [Evening Newspaper].

Hina. (1993, April 19). Uspomena na žrtve holokausta [Memory on the Holocaust victims]. Večernji list [Evening Newspaper].

Hina. (1996, April 23). Politika pomirbe preduvjet je svih naših pobjeda [Politics of reconciliation is the prerequisite of all of our victories]. Novi list [New Newspaper].

Horvatić, I., \& Krpan, V. (Eds.). (2013). Petrinjski žrtvoslovni leksikon Domovinskog rata [Lexicon on Petrinja victims from the Homeland War]. Udruga poginulih i nestalih hrvatskih branitelja podružnica Sisačko-moslavačka županija, Udruga dragovoljaca i veterana Domovinskog rata Republike Hrvatske - ogranak Petrinja, Udruga roditelja poginulih i nestalih branitelja Domovinskog rata - Petrinja, Udruga udovica hrvatskih brantelja iz Domovinskog rata Republike Hrvatske - Udruga Petrinja, Udruga HVIDR-a Grada Petrinje, Matica hrvatska u Petrinji.

Hudelist, D. (2004). Tuđman. Biografija [Tuđman. Biography]. Profil International.

International Criminal Tribunal for the former Yugoslavia/Tribunal Pénal International pour l'ex Yougoslavie. (2002, November 11). Testimony of Mustafa Čandić. Retrieved from http://www. icty.org/x/cases/slobodan_milosevic/trans/en/021111ED.htm.

Izvješće Predsjednika Republike Hrvatske Dr. Franje Tuđmana o stanju hrvatske države i nacije $\mathrm{u}$ 1995. godini [Report of the president of the Republic of Croatia dr Franjo Tuđman on the state of the nation in 1995]. (1996, January 15). Retrieved from http://static1.squarespace. com/static/50a667d9e4b02ac9585b28e4/t/52d525ece4b02a4ced959bfa/1389700588140/ Izvjesce+0+stanju+drzave+i+nacije+1995.pdf.

Jareb, M. (2011). Nezavisna Država Hrvatska i žrtve Drugoga svjetskog rata u povijesnim istraživanjima Franje Tuđmana [Independent State of Croatia and victims of World War II in Franjo Tuđman's historical researches]. In V. Herman Kaurić (Ed.), Dr. Franjo Tuđman u okviru hrvatske historiografije. Zbornik radova sa znanstvenog skupa održanoga u Hrvatskom institutu za povijest u Zagrebu 10. i 11. prosinca 2009. [Dr Franjo Tuđman in Croatian historiography. Proceedings from the scientific conference held in the Croatian Institute of History in Zagreb December 10 and 11 2009] (pp. 279-312). Hrvatski institut za povijest.

Jolić, I. (1991, April-May). Trijumf nacionalne svijesti i državotvornosti [Triumph of the national consciousness and statehood]. Hrvatsko pravo [Croatian right], 2(4-5), 3-4.

Jurčević, J. (2005). Bleiburg: jugoslavenski poratni zločini nad Hrvatima. [Bleiburg: Yugoslav Post-War Crimes against Croats]. Dokumentacijsko informacijsko središte.

Jureško, G. (1993, October 16). HDZ ostaje pokretač hrvatskog preporoda [HDZ stays the initiator of the Croatian revival]. Vjesnik.

Karakaš Obradov, M. (2013a). Iseljavanje Židova iz Hrvatske nakon Drugoga svjetskog rata [Post-war emigration of Jewish population from Croatia to Palestine/Israel]. Historijski zbornik [Historical Magazine], 66(2), 391-404. 
Karakaš Obradov, Marica. (2013b). Prisilne migracije židovskog stanovništva na području Nezavisne Države Hrvatske [Forced migrations of Jewish population In Independent State of Croatia]. Croatia Christiana periodica, 37(72), 153-178. Retrieved from https://hrcak.srce.hr/116108.

Kerenji, E. (2008). Jewish citizens of socialist Yugoslavia: Politics of Jewish identity in a socialist state, 1944-1974 (Doctoral dissertation, The University of Michigan). Retrieved from http://deepblue. lib.umich.edu/bitstream/handle/2027.42/60848/ekerenji_1.pdf?sequence=1.

Klancir, Đ. (1991, October 4). Što zapravo hoće HOS [What does HOS want actually]. Globus.

Koren, S. (2011). 'Korisna prošlost'? Ratovi devedesetih u deklaracijama Hrvatskog sabora ['Useful history? Wars in the 90s in declarations of the Croatian Parliament]. In T. Cipek (Ed.), Kultura sjećanja 1991. Povijesni lomovi i svladavanje prošlosti [The culture of memory 1991. Historical fractions and overcoming the past] (pp. 123-156). Disput.

Lang, S. (1997). Dnevnik Libertas [Journal Libertas]. Pegaz.

Lang, S., Javornik, N., Bakalić, K., Swedlund, S., Ghidi, V., Luetić, V., \& Čulo, B. (1997). "Save Lives” Operation in Liberated Parts of Croatia in 1995: an Emergency Public Health Action to Assist Abandoned Elderly Population. Croatian Medical Journal, 38 (3). Retrieved from http://neuron. mefst.hr/docs/CMJ/issues/1997/38/3/lang.pdf.

Lebel, J. (2007). Until 'The Final Solution’ The Jews in Belgrade 1521-1942. Avotaynu.

Leicht, J., \& Schwarz, P. (1999, December 16). Croatian president Franjo Tudjman dies. World Socialist Web Site. Retrieved from http://www.wsws.org/en/articles/1999/12/tudj-d16.html.

Levin, N. (1973). The Holocaust, The destruction of European Jewry 1933-1945. Schocken.

Lipstadt, D. (1993). Denying the Holocaust. The growing assault on truth and memory. Penguin.

Lobont, F. (2004). Antisemitism and Holocaust denial in post-communist Eastern Europe. In D. Stone (Ed.), The Historiography of the Holocaust (pp. 440-468). Palgrave Macmillan.

Malenica, A. (1997, September 5). Uspostavljeni diplomatski odnosi Hrvatske i Izraela [Established diplomatic relations between Croatia and Israel]. Slobodna Dalmacija [Free Dalmatia].

Margetić, D. (2013, January 27). Ljubo R. Weiss: U Hrvatskoj i dalje ima antisemitizma a i straha od antisemitizma [There is still antisemitism and fear of antisemitism in Croatia]. SEEbiz. Retrieved from http://www.seebiz.eu/ljubo-r-weiss-u-hrvatskoj-i-dalje-ima-antisemitizma-a-istraha-od-antisemitizma/ar-55494/.

Marić, D. (1990, April 6). Izmišljene opasne namjere [Fictional dangerous intentions]. Slobodna Dalmacija [Free Dalmatia].

Marijan, D. (2013). Obrana i pad Vukovara [Defense and fall of Vukovar]. Hrvatski institut za povijest.

Mašić, B. (2010). Stranačka struktura Hrvatskog sabora 1990. - 2010. [Party structure of the Croatian Parliament]. Pravnik [Jurist], 44(89), 67-82.

Matković, B. (2011). Odvođenja i likvidacije ranjenih pripadnika hrvatskih oružanih snaga (HOS) iz zagrebačkih bolnica u svibnju i lipnju 1945. kroz arhivsko gradivo Državnog arhiva u Zagrebu [Arrests and Liquidations of Wounded Members of the Croatian Armed Forces (HOS) Taken from Hospitals in Zagreb by Yugoslav Armed Forces in May and June of 1945 in the Records of State Archives in Zagreb]. Časopis za suvremenu povijest [Journal of Contemporary History], 54 (1), 179-214. Retrieved from https://hrcak.srce.hr/90525.

Matković, S. (2011). Povijesne teme u programima hrvatskih političkih stranaka: 1989. - 1990. [Historical topics in programs of Croatian political parties: 1989-1990]. In T. Cipek (Ed.), Kultura sjećanja 1991. Povijesni lomovi i svladavanje prošlosti [The culture of memory 1991. Historical fractures and overcoming the past] (pp. 109-120). Disput.

Matošić, V. (1991, November 28). Samo domovina [Only homeland]. Nedjeljna Dalmacija [Sunday Dalmatia].

Memorandum of the Serbian Academy of Sciences and Arts, draft. (1986). Retrieved from https:// pescanik.net/wp-content/PDF/memorandum_sanu.pdf.

Mesić pred akademicima: Moj govor bio je verbalna akrobatika; govorio sam ono što su htjeli čuti [Mesić before academics: my speech was verbal acrobatics; I was saying ony what they wanted to hear]. (2006, December 15). Retrieved from http:/www.index.hr/vijesti/clanak/mesicpred-akademicima-moj-govor-bio-je-verbalna-akrobatika-govorio-sam-ono-sto-su-htjelicuti/334994.aspx. 
Mesić: I ja sam bio zaveden falsificiranom veličinom NDH [Mesić: I too was misled by the falsified greatness of NDH]. (2010, February 13). Jutarnji list [Morning Newspaper]. Retrieved from https://www.jutarnji.hr/vijesti/hrvatska/mesic-i-ja-sam-bio-zaveden-falsificiranom-velicinomndh-2224181.

Miletić, A. (1986-1987). Koncentracioni logor Jasenovac 1941-1945. 1-3. [Concentration Camp Jasenovac 1941-1945]. 1-3. Narodna knjiga.

Najbar Agičić, M. (2013). U skladu s marksizmom ili činjenicama? Hrvatska historiografija 1945. 1960. [In accordance with marxism or facts. Croatian historiography 1945-1990]. Ibis grafika.

Napad na Židovsku općinu [Attack on the Jewish Community]. (1991, August 20). Večernji list [Evening Newspaper].

Nazor, A. (2011). Velikosrpska agresija na Hrvatsku 1990-ih/Greater-Serbian aggression against Croatia in the 90s. [Bilingual edition] Hrvatski memorijalno-dokumentacijski centar Domovinskog rata.

Ni mrtvima mir [Peace not even to the dead]. (1991, August 22). Večernji list [Evening Newspaper].

Oraić Tolić, D. (1992). Hrvatsko ratno pismo 1991/92.: apeli, iskazi, pjesme=Croatian war writing 1991/92: appeals, viewpoints, poems. [Bilingual edition] Zavod za znanost o književnosti Filozofskog fakulteta Sveučilišta u Zagrebu.

Pavlaković, V. (2009). Komemorativna kultura Bleiburga, 1990 - 2009. [Commemorative culture of Bleiburg, 1990-2009]. In T. Cipek \& S. Bosto (Eds.), Kultura sjećanja 1945. Povijesni lomovi $i$ svladavanje prošlosti [Culture of memory 1945. Historical fractions and overcoming the past] (pp. 167-194). Disput.

Pavlaković, V. (2011). Sukob, komemoracije i promjene značenja: Meštrovićev paviljon kao prijeporno mjesto sjećanja [Conflict, commemorations and changes in meaning: Meštrović’s pavilion as a contentious place of remembrance]. In: T. Cipek (Ed.), Kultura sjećanja 1991. Povijesni lomovi $i$ svladavanje prošlosti [Memory of culture 1991. Historical fractions and overcoming the past] (pp. 215-238). Disput.

Pecnik, J. (1996). Antisemitizam u srednjoeuropskom kontekstu [Antisemitism in the Central European context]. In I. Goldstein (Ed.), Antisemitizam, holokaust, antifašizam [Anti-Semitism, Holocaust, and antifascism] (pp. 65-79). Židovska općina.

Perković Paloš, A. (2018). Vlada demokratskog jedisntva. [Democratic Unity Government]. (Doctoral dissertation, The University of Split). Retrieved from https://urn.nsk.hr/urn:nbn:hr:172:511218.

Perković Paloš, A. (2020). The Croatian War of Independence. In: M. Marušić (Ed.), Croatia: Past Present and Future Perspectives (pp. 267-294). Nova Science Publishers.

Petrović, V. (2007). (Ne)legitimni revizionizam: Pravo i (pseudo) istoriografske revizije na Zapadu i Istoku [(Un)legitimate revisionism: Law and (pseudo) historiographical revisions in the West and in the East]. In V. Katz (Ed.), Revizija prošlosti na prostorima bivše Jugoslavije [Revision of the past in former Yugoslavia] (pp. 21-42). Institut za istoriju. Retrieved from http://cliohipbih. ba/wp-content/uploads/2015/12/Revizija-prošlosti-na-prostorima-bivše-Jugoslavije.pdf.

Porges, N. (1991, October 7). Appeal to our Jewish brothers and sisters. Retrieved from http://www. porges.net/FamilyTreesBiographies/NenadPorges.html\#a.

Primorac, I. (2000). 'Preseljenje’ i ‘etničko čišćenje’: Izrael i rat na Balkanu ['Transfer’ or 'ethnic cleansing’: Israel and the War in the Balkans]. Politička misao [Croatian Political Science Review], 37(2), 12-23. Retrieved from https://hrcak.srce.hr/27134.

Programske zasade i ciljevi HDZ [HDZ’s program and goals]. (1990). A. G. Matoš.

Radojčić, R. (2009). Izjava. [Statement]. National Security and the Future, 10 (3-4): 49-222.

Radonić, Lj. (2011). Croatia - exhibiting memory and history at the 'shores of Europe'. Culture Unbound 3, 355-367. doi: 10.3384/cu.2000.1525.113355.

Radoš, I. (2005). Tuđman izbliza. Svjedočenja suradnika i protivnika [Tuđman up close: testimonies of associates and opponents]. Profil International.

Ramet, S. (2005). Balkanski babilon [Balkan Babel]. Alinea.

Reich, W. (1996, May 6). Zaustavite Tuđmana [Stop Tuđman]. Feral Tribune.

Reitlinger, G. (1953). The Final Solution. Vallentine.

Rudolf, D. (1999). Rat koji nismo htjeli. Hrvatska 1991 [War we did not want. Croatia 1991]. Nakladni zavod Globus. 
Sadkovich, J. J. (2006). Patriots, villains, and Franjo Tuđman. Review of Croatian History, 2(1), 247280. Retrieved from https://hrcak.srce.hr/15857.

Sadkovich, J. J. (2010a). Tuđman. Prva politička biografija [Tuđman. The First Political Biography]. Trans. Lidija Šimunić Mesić. Večernji posebni proizvodi.

Sadkovich, J. J. (2010b). Forging consensus: How Franjo Tuđman became an authoritarian nationalist. Review of Croatian History, 6(1), 7-35. Retrieved from https://hrcak.srce.hr/67472.

Shafir, M. (2003). Varieties of antisemitism in post-communist East Central Europe: Motivations and Political Discourse (pp. 175-210). Retrieved from http://web.ceu.hu/jewishstudies/yb03/16shafir. pdf.

Silber, L., \& Little, A. (1996). Smrt Jugoslavije [The death of Yugoslavia]. (Anka Katušić-Balen, Trans). "Otokar Keršovani."

Solidarnost sa Židovima [Solidarity with Jews]. (1991, August 22). Večernji list [Evening Newspapers].

Starman, H. (2004). Antisemitism in post-communist Central and Eastern Europe. Anthropology of East Europe Review, 22(2), 65-75. Retrieved from http://scholarworks.iu.edu/journals/index. php/aeer/article/view/303/379.

Stern, K. (1993). Holocaust Denial. The American Jewish Committee. Retrieved from https://www.ajc. org/sites/default/files/pdf/2017-08/HolocaustDenial.pdf.

Sternberg, S. (1991, October 23). Ured za opće poslove Hrvatskog sabora i Vlade Republike Hrvatske [General Administration Office of the Croatian Parliament - Sabor and Croatian Government]. Zagreb, Republika Hrvatska.

Šimić, Z. (1996, April 24). Jasenovac na raskrižju sjećanja i nadanja [Jasenovac on the crossroads of memory and hope]. Vjesnik [News].

Šmidt, J. (1991, December 6). Podrška Hrvatskoj s 'kraja svijeta' [Support to Croatia from 'the end of the world']. Slobodna Dalmacija [Free Dalmatia].

Švob, M. (1997). Židovi u Hrvatskoj. Migracije i promjene u židovskoj populaciji/Jews in Croatia: migrations and changes in Jewish population. [Bilingual edition] KD Miroslav Šalom Freiberger: Židovska općina.

Švob, M. (1998). Promjene u populaciji Židova u Hrvatskoj od XVIII. do XX. stoljeća [Changes in the Jewish population in Croatia from the 18th to 20th century]. In O. Kraus, (Ed.), Dva stoljeća povijesti i kulture Židova u Zagrebu i Hrvatskoj [Two centuries of Jewish history and culture in Zagreb and Croatia] (pp. 287-310). Židovska općina.

Švob, M., Brčić, C., \& Podgorelec, S. (1994). Židovi u Hrvatskoj [Jews in Croatia]. Migracijske teme [Migration Themes], 10(1), 55-84.

Tardelli, T. (1991, May 4). HDZ koči hrvatski narod [HDZ is blocking Croatian people]. Slobodni tjednik [Free Weekly].

Tko je bio Jakov Bienenfeld? [Who was Jakov Bienenfeld?]. (2016, February 9). Večernji list [Evening Newspaper]. Retrieved from https://www.vecernji.hr/vijesti/tko-je-bio-jakovbienenfeld-1058914.

Tomac, Z. (2004). Predsjednik. Protiv krivotvorina i zaborava [The President. Against Falsification and Oblivion]. Slovo M.

Tuđen, B. (1990, February 27). HDZ stranka opasnih namjera [HDZ party of dangerous intentions]. Večernji list [Evening Newspapers].

Tuđman, F. (1989). Bespuća povijesne zbiljnosti. Rasprava o povijesti i filozofiji zlosilja [Horrors of War: historical reality and philosophy]. Nakladni zavod Matice hrvatske.

Tuđman, F. (1995). Usudbene povjestice [History’s fates]. Hrvatska sveučilišna naklada.

Tuđman, F. (1998). Povijesna uloga i programske zadaće HDZ-a u budućem razdoblju [Historical role and program assignments of the HDZ in the future]. In Z. Stublić (Ed.), Zbornik četvrtoga Općeg sabora Hrvatske demokratske zajednice [Proceedings of the Fourth General Convention of the Croatian Democratic Union] (pp. 11-43). Hrvatska demokratska zajednica; Zaklada Hrvatskog državnog zavjeta.

Tuđman, F. (1999). Hrvatska riječ svijetu. Razgovori sa stranim predstavnicima [Croatian word to the world. Conversations with foreign representatives]. Hrvatska sveučilišna naklada, Hrvatski institut za povijest. 
Tuđman, M. (2012). Programiranje istine. Rasprava o preraspodjelama društvenih zaliha znanja [Programming the truth. Discussin the redistribution of social knowledge stocks]. Hrvatska sveučilišna naklada.

Tuđman, M. (Ed.). (2015a). Tuđmanov arhiv. Korespondencija predsjednika Republike Hrvatske dr. Franje Tuđmana od 1990. do 1999. godine, Druga knjiga: Godina priznanja: 1992. [Tuđman's archive. Correspondence of the President of the Republic of Croatia dr Franjo Tuđman from 1990 to 1999, The second book: the year of recognition: 1992]. Hrvatska sveučilišna naklada; Hrvatski institut za povijest.

Tuđman, M. (Ed.). (2015b). Tuđmanov arhiv. Korespondencija predsjednika Republike Hrvatske dr. Franje Tuđmana od 1990. do 1999. godine, Treća knjiga: Godina sukoba: 1993. [Tuđman's archive. Correspondence of the President of the Republic of Croatia dr Franjo Tuđman from1990 to 1999, The third Book: the year of conflict: 1993]. Hrvatska sveučilišna naklada, Hrvatski institut za povijest.

Tuđman, M. (Ed.). (2015c). Tuđmanov arhiv. Korespondencija predsjednika Republike Hrvatske dr. Franje Tuđmana od 1990. do 1999. godine, Četvrta knjiga: Godine pobjede: 1994. i 1995.[Tuđman's archive. Correspondence of the President of the Republic of Croatia dr Franjo Tuđman from 1990 to 1999, The fourth book: the years of victory: 1994 and 1995]. Hrvatska sveučilišna naklada; Hrvatski institut za povijest.

Tuđman, M. (Ed.). (2015d). Tuđmanov arhiv. Korespondencija predsjednika Republike Hrvatske dr. Franje Tuđmana od 1990. do 1999. godine, Peta knjiga: Godine povratka: 1996. i 1997. [Tuđman's archive. Correspondence of the President of the Republic of Croatia dr Franjo Tuđman from1990 to 1999, The fifth book: the year of return: 1996 and 1997]. Hrvatska sveučilišna naklada; Hrvatski institut za povijest.

Tuđman, M. (Ed.). (2015e). Tuđmanov arhiv. Korespondencija predsjednika Republike Hrvatske dr. Franje Tuđmana od 1990. do 1999. godine, Prva knjiga: Godina stvaranja i obrane: 1992. [Tuđman's archive. Correspondence of the President of the Republic of Croatia dr Franjo Tuđman from 1990 to 1999, The first book: the year of creation and defense: 1991]. Hrvatska sveučilišna naklada; Hrvatski institut za povijest.

Ustav Republike Hrvatske [Constitution of the Republic of Croatia]. (1990, December 22). Narodne novine 56 [The People's Newspaper 56]. Retrieved from https://narodne-novine.nn.hr/clanci/ sluzbeni/1990_12_56_1092.html.

Vulesica, M. (2009). Povijest i razmatranje pojma antisemitizam [History and discussing the term anti-Semitism]. Studia lexicographica, 3(1-2; 4-5), 65-75. Retrieved from https://hrcak.srce. hr/110593.

Williams, D. (2012). Rewriting history. Holocaust revisionism today. HOPE not hate. Retrieved from https://silo.tips/download/rewriting-history-holocaust-revisionism-today-hope-not-hate.

Zakon o blagdanima i neradnim danima u Republici Hrvatskoj [The Law on holidays and nonworking days in the Republic of Croatia]. (1991, March 25). Narodne novine 14/91 [Official Gazette 14/91]. Retrieved from https://narodne-novine.nn.hr/clanci/sluzbeni/1991_03_14_383.html.

Zakon o blagdanima, spomendanima i neradnim danima u Republici Hrvatskoj [The Law on holidays, memorial day and non-working days in the Republic of Croatia]. (1996, April 30). Narodne novine 33/96 [Official Gazette 33/96]. Retrieved from https://narodne-novine.nn.hr/ clanci/sluzbeni/1996_04_33_674.html.

Zlatković Winter, J. (1995). Židovi u Hrvatskoj: migracije, etno-socijalna obilježja, status i odnos s okolinom [Jews in Croatia: migration, ethno-social traits, status and relations with the general community]. Migracijske teme [Migration Themes], 11(3-4), 329-342. Retrieved from https:// hrcak.srce.hr/126961.

Zuroff, E. (2005). Eastern Europe: Antisemitism in the Wake of Holocaust-related Issues. Jewish Political Studies Review. Retrieved from http://www.jcpa.org/phas/phas-zuroff-s05.htm.

Židovi pridonose slobodi Hrvatske [Jews are contributing to Croatia’s freedom]. (1991, October 28). Slobodna Dalmacija [Free Dalmatia].

Živaković-Kerže, Z. (2006). Stradanja i pamćenja: Holokaust u Osijeku i život koji se nastavlja [Suffering and remembrance: the Holocaust in Osijek and life that continues]. Židovska općina Osijek.

Živković, M. (2000). The Wish to be a Jew: The power of the Jewish trope in the Yugoslav conflict. Cahiers de l'Urmis, 6, 69-84. Retrieved from http://urmis.revues.org/323?file=1 